\title{
Mechanistic Studies of the Palladium-Catalyzed Copolymerization of Ethylene and $\alpha$-Olefins with Methyl Acrylate
}

\author{
Stefan Mecking, ${ }^{\dagger}$ Lynda K. Johnson, ${ }^{\dagger,}$ Lin Wang, ${ }^{\ddagger}$ and Maurice Brookhart $*, \dagger$ \\ Contribution from the Department of Chemistry, University of North Carolina at Chapel Hill, \\ Chapel Hill, North Carolina 27599-3290, and DuPont Central Research and Development, \\ Wilmington, Delaware 19880-0328
}

\begin{abstract}
Mechanistic aspects of palladium-catalyzed insertion copolymerizations of ethylene and $\alpha$-olefins with methyl acrylate to give high molar mass polymers are described. Complexes $\left[\left(\mathrm{N}^{\wedge} \mathrm{N}\right) \mathrm{Pd}\left(\mathrm{CH}_{2}\right){ }_{3} \mathrm{C}(\mathrm{O})\right.$ $\mathrm{OMe}] \mathrm{BAr}_{4}^{\prime}(\mathbf{2})$ or $\left[\left(\mathrm{N}^{\wedge} \mathrm{N}\right) \mathrm{Pd}\left(\mathrm{CH}_{3}\right)(\mathrm{L})\right] \mathrm{BAr}_{4}{ }_{4}\left(\mathbf{1}: \mathrm{L}=\mathrm{OEt}_{2} ; 3: \mathrm{L} \equiv \mathrm{NCMe}_{4}\right.$ 4: $\left.\mathrm{L} \equiv \mathrm{NCAr}^{\prime}\right)\left(\mathrm{N}^{\wedge} \mathrm{N} \equiv\right.$ $\mathrm{ArN}=\mathrm{C}(\mathrm{R})-\mathrm{C}(\mathrm{R})=\mathrm{NAr}$, e.g., $\left.\mathrm{Ar} \equiv 2,6-\mathrm{C}_{6} \mathrm{H}_{3}(i-\mathrm{Pr})_{2}, \mathrm{R} \equiv \mathrm{H}(\mathbf{a}), \mathrm{Me}(\mathbf{b}) ; \mathrm{Ar}^{\prime} \equiv 3,5-\mathrm{C}_{6} \mathrm{H}_{3}\left(\mathrm{CF}_{3}\right)_{2}\right)$ with bulky substituted $\alpha$-diimine ligands were used as catalyst precursors. The copolymers are highly branched, the acrylate comonomer being incorporated predominantly at the ends of branches as $-\mathrm{CH}_{2} \mathrm{CH}_{2} \mathrm{C}(\mathrm{O}) \mathrm{OMe}$ groups. The effects of reaction conditions and catalyst structure on the copolymerization reaction are rationalized. Lowtemperature NMR studies show that migratory insertion in the $\eta^{2}$-methyl acrylate $(\mathrm{MA})$ complex $\left[\left(\mathrm{N}^{\wedge} \mathrm{N}\right)\right.$ $\left.\operatorname{PdMe}\left\{\mathrm{H}_{2} \mathrm{C}=\mathrm{CHC}(\mathrm{O}) \mathrm{OMe}\right\}\right]^{+}(\mathbf{5})$ occurs to give initially the 2,1 -insertion product $\left[\left(\mathrm{N}^{\wedge} \mathrm{N}\right) \mathrm{PdCH}\left(\mathrm{CH}_{2} \mathrm{CH}_{3}\right) \mathrm{C}\right.$ $(\mathrm{O}) \mathrm{OMe}]^{+}(\mathbf{6})$, which rearranges stepwise to yield $\mathbf{2}$ as the final product upon warming to $-20{ }^{\circ} \mathrm{C}$. Activation parameters $\left(\Delta H^{\ddagger}=12.1 \pm 1.4 \mathrm{kcal} / \mathrm{mol}\right.$ and $\left.\Delta S^{\ddagger}=-14.1 \pm 7.0 \mathrm{eu}\right)$ were determined for the conversion of 5a to 6a. Rates of ethylene homopolymerization observed in preparative-scale polymerizations $\left(1.2 \mathrm{~s}^{-1}\right.$ at 25 ${ }^{\circ} \mathrm{C}, \Delta G^{\ddagger}=17.4 \mathrm{kcal} / \mathrm{mol}$ for $\left.\mathbf{2 b}\right)$ correspond well with low-temperature NMR kinetic data for migratory insertion of ethylene in $\left[\left(\mathrm{N}^{\wedge} \mathrm{N}\right) \mathrm{Pd}\left\{\left(\mathrm{CH}_{2}\right)_{2 n} \mathrm{Me}\right\}\left(\mathrm{H}_{2} \mathrm{C}=\mathrm{CH}_{2}\right)\right]^{+}$. Relative binding affinities of olefins to the metal center were also studied. For $\left[\left(\mathrm{N}^{\wedge} \mathrm{N}\right) \mathrm{PdMe}\left(\mathrm{H}_{2} \mathrm{C}=\mathrm{CH}_{2}\right)\right]^{+}+\mathrm{MA} \rightleftharpoons \mathbf{5 a}+\mathrm{H}_{2} \mathrm{C}=\mathrm{CH}_{2}, K_{\text {eq }}\left(-95^{\circ} \mathrm{C}\right)=$ $(1.0 \pm 0.3) \times 10^{-6}$ was determined. Combination of the above studies provides a mechanistic model that agrees well with acrylate incorporations observed in copolymerization experiments. Data obtained for equilibria $2+\mathrm{H}_{2} \mathrm{C}=\mathrm{CHR}^{\prime \prime} \rightleftharpoons\left[\left(\mathrm{N}^{\wedge} \mathrm{N}\right) \mathrm{Pd}\left\{\left(\mathrm{CH}_{2}\right)_{3} \mathrm{C}(\mathrm{O}) \mathrm{OMe}\right\}\left(\mathrm{H}_{2} \mathrm{C}=\mathrm{CHR}^{\prime \prime}\right)\right]^{+}\left(\mathrm{R}^{\prime \prime} \equiv \mathrm{H}, \mathrm{Me},{ }^{n} \mathrm{C}_{4} \mathrm{H}_{9}\right)$ shows that chelating coordination of the carbonyl group is favored over olefin coordination at room temperature. Formation of chelates analogous to $\mathbf{2}$ during the copolymerization is assumed to render the subsequent monomer insertion a turnover-limiting step.
\end{abstract}

\section{Introduction}

The development of an insertion-type olefin polymerization catalyst compatible with readily available polar-functionalized monomers $\mathrm{H}_{2} \mathrm{C}=\mathrm{CHX}(\mathrm{X} \equiv$ e.g., $\mathrm{C}(\mathrm{O}) \mathrm{OR}, \mathrm{OC}(\mathrm{O}) \mathrm{R})$ would potentially offer a low-pressure, low-temperature route to a wide range of functionalized copolymers. This development might enable the synthesis of new polymer structures or offer an alternate route to commercially available copolymers such as ethylene-acrylate and ethylene-vinyl acetate copolymers, which are presently produced by radical polymerizations in highpressure reactors. ${ }^{1}$ Although Ziegler-Natta and related catalysts based on early transition metal $\mathrm{d}^{0}$-complexes are extensively used for the coordination polymerization of nonpolar olefins such as ethylene and propylene, the use of these catalysts in the copolymerization of functionalized olefins has been limited due to their highly oxophilic nature. ${ }^{2}$ For example, the polymerizations by early metals of olefins containing a functional group in a remote position to the vinyl group have been reported, but these reactions are currently limited to special substrates. ${ }^{3,4}$

\footnotetext{
University of North Carolina at Chapel Hill.

$¥$ DuPont Central Research and Development.

(1) Doak, K. W. In Encyclopedia of Polymer Science and Engineering; Mark, H. F., Ed.; John Wiley and Sons: New York, 1986; Vol. 6, pp 386429 .
}

The development of polymerization catalysts incorporating late transition metals is a promising area of research, since late metals are typically less oxophilic, and thus more functionalgroup tolerant, than early metals. For example, Ru-based metathesis catalysts have been developed that are compatible with a wide range of functional group-containing olefins and are active in aqueous media. ${ }^{5}$ Examples of the functional-group

(2) As leading references, see: (a) Coates, G. W.; Waymouth, R. M. Science 1995, 267, 217-219. (b) Yang, X.; Stern, C. L.; Marks, T. J. J. Am. Chem. Soc. 1994, 116, 10015-10031. (c) Coughlin, E. B.; Bercaw, J. E. J. Am. Chem. Soc. 1992, 114, 7606-7607. (d) Crowther, D. J.; Baenziger, N. C.; Jordan, R. F. J. Am. Chem. Soc. 1991, 113, 1455-1457. (e) Kaminsky, W.; Külper, K.; Brintzinger, H. H.; Wild, F. R. W. P. Angew. Chem., Int. Ed. Engl. 1985, 24, 507-508. (f) Ewen, J. A. J. Am. Chem. Soc. 1984, 106, 6355-6364. For recent reviews, see: (g) Brintzinger, $\mathrm{H}$. H.; Fischer, D. Mulhaupt, R.; Rieger, B.; Waymouth, R. Angew. Chem., Int. Ed. Engl. 1995, 34, 1143-1170. (h) Coates, G. W.; Waymouth, R. M. In Comprehensive Organometallic Chemistry II; Abel, E. W., Stone, F. G. A., Wilkinson, G., Eds.; Hegedus, L., Vol. Ed.; Pergamon Press: 1995; Vol. 12, pp 1193-1208.

(3) (a) Chung, T. C. Macromolecules 1988, 21, 865-869. (b) Chung, T. C.; Rhubright, D. Macromolecules 1993, 26, 3019-3025. (c) Kesti, M. R.; Coates, G. W.; Waymouth, R. M. J. Am. Chem. Soc. 1992, 114, $9679-$ 9680. (d) Aaltonen, P.; Löfgren, B. Macromolecules 1995, 28, 5353-5357. (e) Galimberti, M.; Giannini, U.; Albizatti, E.; Caldari, S.; Abis, L. J. Mol. Catal. 1995, 101, 1-10.

(4) The preparation of ethylene-acrylate A-B block-copolymers has recently been reported. However, the ethylene block must be grown first, presumably due to an irreversible change in polymerization mechanism Yasuda, H.; Ihara, E. Macromol. Chem. Phys. 1995, 196, 2417-2441. 
Scheme 1
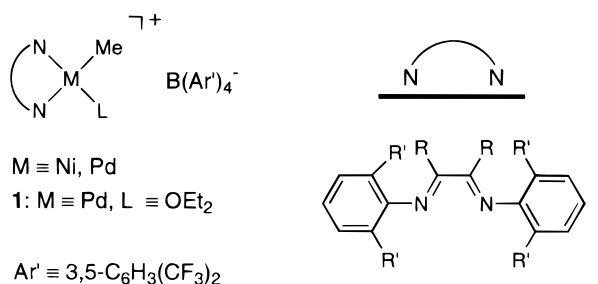

(a) $\mathrm{R} \equiv H, \mathrm{R}^{\prime} \equiv{ }^{\prime} \mathrm{Pr}$

(b) $\mathrm{R} \equiv \mathrm{Me}, \mathrm{R}^{\prime} \equiv{ }^{i} \mathrm{Pr}$

(c)

$\mathrm{M} \equiv \mathrm{Ni}, \mathrm{Pd}$

1: $M \equiv P d, L \equiv \mathrm{OEt}_{2}$

$A r^{\prime} \equiv 3,5-\mathrm{C}_{6} \mathrm{H}_{3}\left(\mathrm{CF}_{3}\right)_{2}$

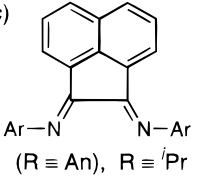

(d) $\mathrm{R} \equiv \mathrm{Me}, \mathrm{R}^{\prime} \equiv \mathrm{Me}$

tolerance of late metals in insertion-type reactions include reports on $\mathrm{Ru}, \mathrm{Rh}, \mathrm{Ni}$, and $\mathrm{Pd}$ catalysts for the dimerization of acrylates and the codimerization of ethylene and acrylates. ${ }^{6,7}$ In these acrylate dimerizations and in numerous other insertion reactions of late metals with olefins, $\beta$-hydride elimination competes effectively with chain growth, resulting in the formation of dimers or oligomers. ${ }^{6,8}$ A prominent example is the synthesis of linear $\alpha$-olefins from ethylene in the Ni-catalyzed Shell Higher Olefin Process. ${ }^{8 a, b}$ Recently, however, a number of ethylene polymerization catalysts based on $\mathrm{Co}, \mathrm{Rh}$, and $\mathrm{Ni}$ have been described. ${ }^{9}$ Although the polymerization of $\alpha$-olefins by these catalysts has not been achieved, ${ }^{10,11}$ a Ni catalyst has been reported to copolymerize ethylene with olefins containing a functional group in a remote position to the olefin. ${ }^{12,13}$

We recently reported the development of highly active, cationic $\mathrm{Ni}(\mathrm{II})$ - and $\mathrm{Pd}(\mathrm{II})$-based catalysts of the general type $\left[\left(\mathrm{N}^{\wedge} \mathrm{N}\right) \mathrm{M}(\mathrm{Me})(\mathrm{L})\right]^{+}$(Scheme 1) that polymerize ethylene and

(5) As leading references, see: (a) Moore, J. S. In Comprehensive Organometallic Chemistry II; Abel, E. W., Stone, F. G. A., Wilkinson, G. Eds.; Hegedus, L., Vol. Ed.; Pergamon Press: 1995; Vol. 12, pp 12091232, and references therein. (b) Novak, B. M.; Grubbs, R. H. J. Am. Chem. Soc. 1988, 110, 7542-7543. (c) Nguyen, S. T.; Johnson, L. K.; Grubbs, R. H. J. Am. Chem. Soc. 1992, 114, 3974-3975. (d) Lynn, D. M.; Kanaoka, S.; Grubbs, R. H. J. Am. Chem. Soc. 1996, 118, 784-790. (e) Stumpf, A. W.; Saive, E.; Demonceau, A.; Noels, F. J. Chem. Soc., Chem. Commun. 1995, 1127-1128.

(6) (a) Alderson, T.; Jenner, E. L.; Lindsey, R. V., Jr. J. Am. Chem. Soc. 1965, 87, 5638-5645. (b) Barlow, M. G.; Bryant, M. J.; Haszeldine, R. N.; Mackie, A. G. J. Organomet. Chem. 1970, 21, 215-226. (c) Oehme, G.; Pracejus, H. Tetrahedron Lett. 1979, 343-344. (d) Nugent, W. A.; Hobbs, F. W., Jr. J. Org. Chem. 1983, 48, 5364-5366. (e) Grenouillet, P.; Neibecker, D.; Tkatchenko, I. Organometallics 1984, 3, 1130-1132. (f) Nugent, W. A.; McKinney, R. J. J. Mol. Catal. 1985, 29, 65-76. (g) McKinney, R. J.; Colton, M. C. Organometallics 1986, 5, 1080-1085. (h) Wilke, G. Angew. Chem. 1988, 100, 189-211. (i) Brookhart, M.; SaboEtienne, S. J. Am. Chem. Soc. 1991, 113, 2777-2779. (j) Brookhart, M. Hauptman, E. J. Am. Chem. Soc. 1992, 114, 4437-4439. (k) Hauptman, E.; Sabo-Etienne, S.; White, P. S.; Brookhart, M.; Garner, J. M.; Fagan, P. J ; Calabrese, J. C. J. Am. Chem. Soc. 1994, 116, 8038-8060, and references cited therein. (1) DiRenzo, G. M.; White, P. S.; Brookhart, M. J. Am. Chem. Soc. 1996, 118, 6225-6234.

(7) Behr, A. In Industrial Applications of Homogeneous Catalysis; Mortreux, A., Petit, F., Eds.; D. Reidel Publishing Company: Dordrecht 1988; pp 156-167.

(8) (a) Peuckert, M.; Keim, W. Organometallics 1983, 2, 594-597. (b) Keim, W. Angew. Chem., Int. Ed. Engl. 1990, 29, 235-244. (c) Rix, F. C.; Brookhart, M. J. Am. Chem. Soc. 1995, 117, 1137-1138.

(9) (a) Keim, W.; Kowaldt, F. H.; Goddard, R.; Krüger, C. Angew. Chem., Int. Ed. Engl. 1978, 17, 466-467. (b) Schmidt, G. F.; Brookhart, M. J. Am. Chem. Soc. 1985, 107, 1443-1444. (c) Brookhart, M.; Volpe, Jr., A F.; Lincoln, D. M.; Horvath, I. T.; Millar, J. M. J. Am. Chem. Soc. 1990, 112, 5634-5636. (d) Ostaja Starzewski, K. A.; Witte, J.; Reichert, K. H.; Vasiliou, G. In Transition Metals and Organometallics as Catalysts for Olefin Polymerization; Kaminsky, W., Sinn, H., Eds.; Springer-Verlag: Berlin Heidelberg, 1988; pp 349-360. (e) Wang, L.; Lu, R. S.; Bau, R.; Flood, T. C. J. Am. Chem. Soc. 1993, 115, 6999-7000.

(10) Certain $\mathrm{Ni}$ (II) catalysts convert $\alpha$-olefins to oligomers with degrees of polymerization of ca. 4-20: (a) Möhring, V. M.; Fink, G. Angew. Chem., Int. Ed. Engl. 1985, 24, 1001-1003. (b) Schubbe, R.; Angermund, K ; Fink, G.; Goddard, R. Macromol. Chem. Phys. 1995, 196, 467-468.

(11) For an early example of the observation of both 2,1- and 1,2 insertions in $\alpha$-olefin dimerizations by $\mathrm{Pd}(\mathrm{II})$-based catalysts modified with bipyridyl-type ligands, see: (a) Drent, E. Eur. Pat. Spec. 1986, 170311. (b) Drent, E. Pure Appl. Chem. 1990, 62, 661-669.

$\alpha$-olefins. ${ }^{14}$ The palladium complexes also catalyze the copolymerization of ethylene and $\alpha$-olefins with functionalized olefins such as acrylates and methyl vinyl ketone. ${ }^{15}$ A key feature of these $\mathrm{Ni}$ and $\mathrm{Pd}$ catalysts is the incorporation of bulky substituents $\mathrm{R}^{\prime}$ on the aryl groups of the $\alpha$-diimine ligand, which block associative olefin exchange and thus effectively retard chain transfer (Scheme 2). ${ }^{14,16}$ We present here a full account of the mechanistic aspects of the copolymerization of ethylene and $\alpha$-olefins with methyl acrylate. The effect of catalyst structure and reaction conditions is discussed based on mechanistic insight obtained from low-temperature NMR experiments. Full details of the characterization of the unique, highly branched copolymers $^{17}$ and the functional-group tolerance of these catalysts ${ }^{18,19}$ will be reported separately.

\section{Results and Discussion}

A. Copolymerization Reactions. Employing cationic palladium catalysts with bulky substituted $\alpha$-diimine ligands to copolymerize ethylene or an $\alpha$-olefin with methyl acrylate yields a high molecular weight random copolymer (eq 1). Similar to the corresponding ethylene or $\alpha$-olefin homopolymers synthesized with these catalysts, the copolymers are highly branched, the ester groups being located predominantly at the ends of branches in the manner shown $(x \geq 0) .{ }^{17}$

$$
\begin{aligned}
& \nearrow^{\mathrm{R}}+J^{\mathrm{C}(\mathrm{O}) \mathrm{OMe}} \frac{\stackrel{1,2,3 \text { or } \mathbf{4}}{\mathrm{CH}_{2} \mathrm{Cl}_{2}}}{\frac{1-6 \mathrm{~atm}}{25-35^{\circ} \mathrm{C}}} \\
& \left(R^{\prime \prime} \equiv H, M e, n \text {-alkyl) } 25-35^{\circ} \mathrm{C}\right.
\end{aligned}
$$

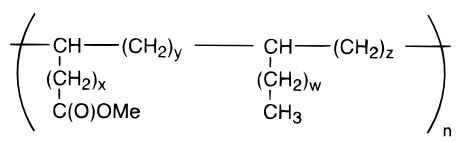

$$
\begin{aligned}
& \text { highly branched, high molecular weight } \\
& \text { random copolymer }
\end{aligned}
$$

The chelate complexes $\mathbf{2}$ or the nitrile adducts $\mathbf{3}$ and $\mathbf{4}$ were generally preferred to the ether-adducts $\mathbf{1}$ for preparative-scale

(12) Klabunde, U.; Ittel, S. D. J. Mol. Catal. 1987, 41, 123-134.

(13) A palladium-catalyzed reaction of ethylene with methyl acrylate has been reported to give low molecular weight materials $\left(M_{\mathrm{n}} \leq 4100\right)$, but no detailed product characterizations were given: Drent, E.; Pello, D. H. L.; Jager, W. W. Eur. Pat. Appl. 1994, 589527.

(14) Johnson, L. K.; Killian, C. M.; Brookhart, M. J. Am. Chem. Soc. 1995, 117, 6414-6415 (experimental details and NMR data are given in the Supporting Information)

(15) Johnson, L. K.; Mecking, S.; Brookhart, M. J. Am. Chem. Soc. 1996 118, 267-268 (experimental details and NMR data are given in the Supporting Information).

(16) The use of $\alpha$-diimine ligands in transition-metal-catalyzed reactions has been extensively researched. As leading references, see: (a) van Koten, G.; Vrieze, K. Adv. Organomet. Chem. 1982, 21, 151-239. (b) van Asselt, R.; Gielens, E. E. C. G.; Rulke, R. E.; Vrieze, K.; Elsevier: C. J. J. Am. Chem. Soc. 1994, 116, 977-985. For the development and synthesis of the $\mathrm{N}$-aryl-substituted $\alpha$-diimine ligands used in this research, see: (c) $\mathrm{R}=\mathrm{H}$, Me: tom Dieck, H.; Svoboda, M.; Grieser, T. Z. Naturforsch 1981, 36b, 823-832. (d) R = An: van Asselt, R.; Elsevier: C. J.; Smeets, W. J. J. Spek, A. L.; Benedix, R. Recl. Trav. Chim. Pays-Bas 1994, 113, 88-98.

(17) The detailed nature of the branching in the novel ethylene- and $\alpha$-olefin polymers and the corresponding copolymers with functionalized olefins has been extensively studied by $2 \mathrm{D}-{ }^{13} \mathrm{C}$ NMR spectroscopy: McLain, S.; McCord, E., manuscript in preparation.

(18) For example, methyl vinyl ketone, numerous acrylates besides MA (e.g., acrylic acid), and other polar monomers have been copolymerized with ethylene by the palladium catalysts. ${ }^{15,19}$ In addition, polymerizations using the palladium catalysts have been carried out in water. ${ }^{19}$ The synthesis and reactivity of nickel chelate complexes and the functional-group tolerance of the nickel catalysts has also been explored. ${ }^{19}$

(19) (a) Brookhart, M. S.; Johnson, L. K.; Killian, C. M.; Arthur, S. D.; Feldman, J.; McCord, E. F.; McLain, S. J ; Kreutzer, K. A.; Bennett, A. M.; Coughlin, B. E.; Ittel, S. D.; Parthasarathy, A.; Tempel, D. J. Pat. Appl. WO 96/23010, 1996. (b) Brookhart, M. S.; Arthur, S. D.; Feldman, J.; Johnson, L. K.; McLain, S. J.; McCord, E. F.; Mecking, S.; Wang, L.; Wang, Y., unpublished results. 
Scheme 2

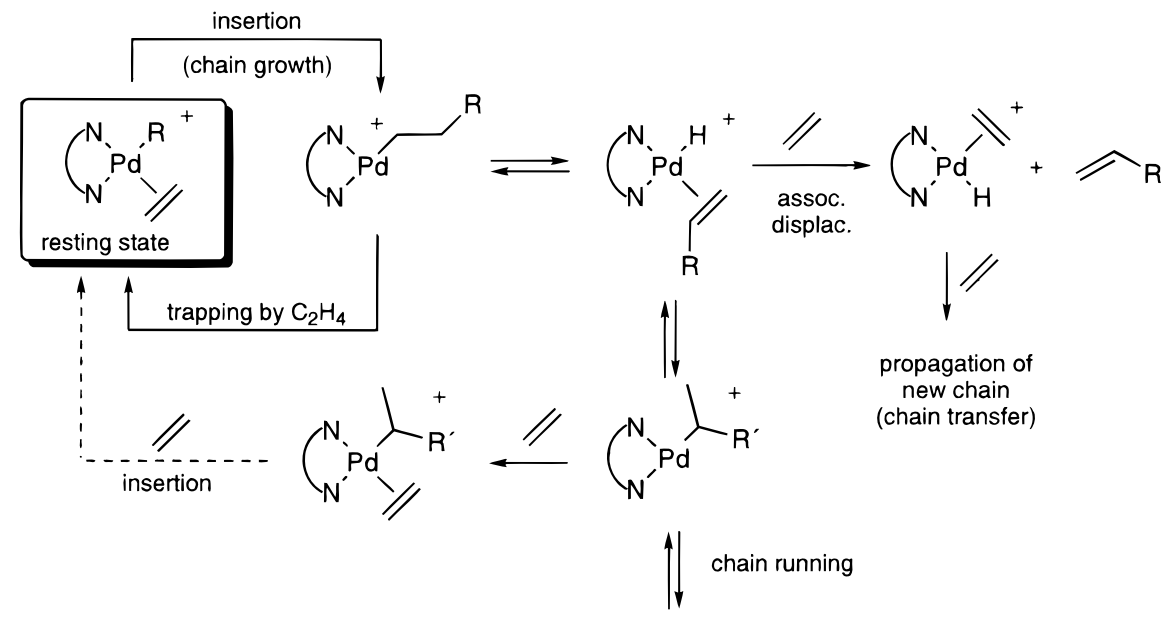

Table 1. Ethylene-MA Copolymerization and Ethylene Homopolymerization: Effect of Reaction Conditions ${ }^{f}$

\begin{tabular}{|c|c|c|c|c|c|c|c|c|c|c|}
\hline \multirow[b]{3}{*}{ entry } & \multirow[b]{3}{*}{ cat. } & & & \multicolumn{4}{|c|}{ results } & \multicolumn{3}{|c|}{ polymer properties } \\
\hline & & \multicolumn{2}{|c|}{ react. conditions } & \multirow{2}{*}{$\begin{array}{l}\text { polymer } \\
\text { yield }(\mathrm{g})\end{array}$} & \multirow{2}{*}{$\begin{array}{c}\text { comon. } \\
\text { incorp. }{ }^{b}(\%)\end{array}$} & \multicolumn{2}{|c|}{$\mathrm{TON}^{d}$} & \multirow{2}{*}{$\begin{array}{c}M_{\mathrm{n}}{ }^{a} \\
\left(\times 10^{-3}\right)\end{array}$} & \multirow[b]{2}{*}{$M_{\mathrm{w}} / M_{\mathrm{n}}$} & \multirow{2}{*}{$\begin{array}{c}\text { branches/ } \\
1000 \mathrm{C}\end{array}$} \\
\hline & & [MA] (M) & $\mathrm{p( \operatorname {atm } ) ^ { e }}$ & & & $\mathrm{E}$ & $\overline{\text { MA }}$ & & & \\
\hline 1 & $2 b$ & 0.6 & 2 & 22.2 & 1.0 & 7710 & 78 & 88 & 1.8 & 103 \\
\hline 2 & $2 \mathbf{b}$ & 2.9 & 2 & 4.3 & 6.1 & 1290 & 84 & 26 & 1.6 & 103 \\
\hline 3 & $2 b$ & 5.8 & 2 & 1.8 & 12.1 & 455 & 63 & 11 & 1.6 & 105 \\
\hline 4 & $2 \mathrm{~b}$ & 5.8 & 6 & 11.2 & 4.0 & 3560 & 148 & 42 & 1.8 & 97 \\
\hline 5 & $2 b$ & & 2 & 8.8 & & 30160 & & $297^{c}$ & $3.5^{c}$ & 102 \\
\hline 6 & $2 b$ & & 11 & 13.7 & & 48700 & & $490^{c}$ & $2.7^{c}$ & 100 \\
\hline 7 & $2 \mathrm{~b}$ & & 29 & 8.1 & & 28480 & & $496^{c}$ & $3.0^{c}$ & 98 \\
\hline 8 & $2 d$ & & 11 & 3.7 & & 13300 & & $445 / 28^{c}$ & & 106 \\
\hline
\end{tabular}

${ }^{a}$ Determined by GPC vs polystyrene standards, uncorrected. ${ }^{b} \mathrm{Mol} \% .{ }^{c}$ Bimodal distribution. ${ }^{d}$ Turnover number $\equiv$ mole substrate converted per mole catalyst. ${ }^{e}$ E.g. $2 \mathrm{~atm} \equiv 1$ atmg. ${ }^{f} 0.1 \mathrm{mmol}$ catalyst (entries 5-8: $0.01 \mathrm{mmol}$ ); solvent: $\mathrm{CH}_{2} \mathrm{Cl}_{2}$ (total volume $\mathrm{CH}_{2} \mathrm{Cl}_{2}$ and comonomer: 100 $\mathrm{mL})$; temperature: $35^{\circ} \mathrm{C}$ (entries $\left.5-8: 25^{\circ} \mathrm{C}\right)$; reaction time: $18.5 \mathrm{~h}$.

polymerizations, as the former are air- and temperature-stable and can be prepared readily from $\left[\left(\mathrm{N}^{\wedge} \mathrm{N}\right) \mathrm{PdMeCl}\right], \mathrm{NaBAr}_{4}^{\prime}$ and

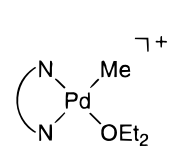

1

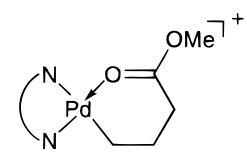

2

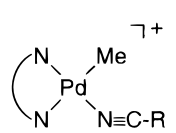

3: $\mathrm{R} \equiv \mathrm{Me}$

4: $R \equiv A r^{\prime \prime}$ counterion: $\mathrm{B}\left(\mathrm{Ar}^{\prime}\right)_{4}{ }^{-}$or $\mathrm{SbF}_{6}^{-}$

$A r^{\prime}, A r^{\prime \prime} \equiv 3,5-\left(\mathrm{CF}_{3}\right)_{2} \mathrm{C}_{6} \mathrm{H}_{3}$

the acrylate or nitrile. ${ }^{20}$ Under the conditions reported here, the results of polymerization experiments were largely independent of the precursor employed. ${ }^{21}$

1. Copolymerization of Ethylene with Methyl Acrylate. The effects of catalyst structure and reaction parameters were

(20) The high lability of $\mathrm{Et}_{2} \mathrm{O}$ results in the thermal instability of $\mathbf{1}$; however, the lability of $\mathrm{Et}_{2} \mathrm{O}$ also makes 1 a very useful precursor for lowtemperature NMR studies. Decomposition of $\mathbf{1}\left(\mathrm{R}^{\prime}=i\right.$-Pr) occurs upon activation of one of the $\mathrm{CH}_{3}$ bonds of the isopropyl substituent by $\mathrm{Pd}$, resulting in the evolution of methane and formation of a chelate complex: Johnson, L. K.; Tempel, D.; Brookhart, M., unpublished results.

(21) Concerning activation of ethylene homopolymerizations using chelates $\mathbf{2}$ as catalyst precursors, the relative amount of unactivated chelate 2b was determined by ${ }^{1} \mathrm{H}$ NMR analysis (integrals of OMe-groups) of the ester end group of the polymer vs the unreacted chelate in $1 \mathrm{~h}$ runs. After $1 \mathrm{~h}$, at 2 atm $71 \%$ of the chelate had been activated, whereas at 29 atm virtually no unactivated chelate remained. These data correspond well to the productivities observed in these experiments and to productivity observed using the ether complex $\mathbf{1}$, which is activated instantaneously, as a catalyst precursor. Thus, the rate of activation of $\mathbf{2}$ is only significant at low ethylene pressure in combination with short reaction times; in $18 \mathrm{~h}$ experiments, even at only $1 \mathrm{~atm}$, the rate of activation does not affect the outcome of polymerizations significantly. studied extensively using ethylene and methyl acrylate (MA) as comonomers. The effect of monomer concentrations is shown in Table 1. Gas solubility experiments showed that the solubility of ethylene in neat MA and in methylene chloride (used as a solvent in copolymerization experiments) does not differ significantly. Thus, varying the MA concentration at a given ethylene pressure does not change the ethylene concentration. The solubility of ethylene in methylene chloride was determined to be $0.18 \mathrm{~mol} / \mathrm{L}$ atm in the range from 1 to $11 \mathrm{~atm}$ at $25{ }^{\circ} \mathrm{C}$. The fraction of MA incorporation is directly proportional to the MA concentration in the reaction solution (Table 1, entries 1-3 and Figure 1). The polymer yield falls as the MA incorporation increases, due to a decrease in ethylene turnovers, while the turnover numbers for MA remain roughly the same. In comparison to ethylene homopolymerization experiments $^{22}$ (Table 1, entries 5-8), productivities of the copolymerizations are greatly reduced. These observations are in accord with the mechanistic model depicted in Scheme 3, which is supported by low-temperature NMR experiments (vide infra). After an insertion of acrylate, rearrangement can yield a stable chelate complex. Coordination of the carbonyl group to palladium inhibits the next olefin insertion and renders it a turnover-limiting step.

(22) Additional data for Pd-catalyzed homopolymerizations of ethylene ( $1 \mathrm{~atm})$ and $\alpha$-olefins by the $\mathrm{Et}_{2} \mathrm{O}$ adducts 1 is published in Table 1 of ref 14. Please note, in this table $M_{\mathrm{n}}$ and $M_{\mathrm{w}}$ reported in entry 1 for the ethylene homopolymer produced by $1 \mathrm{a}$ are off by a factor of 10 ; correct values are $M_{\mathrm{n}}=6000$ and $M_{\mathrm{w}}=18000$. The low values for the molecular weights of the Pd-produced homopolymers in ref 14 as compared to the values reported in Table 1 of this report are mainly due to mass-transfer-limited conditions in ref 14. 
Scheme 3

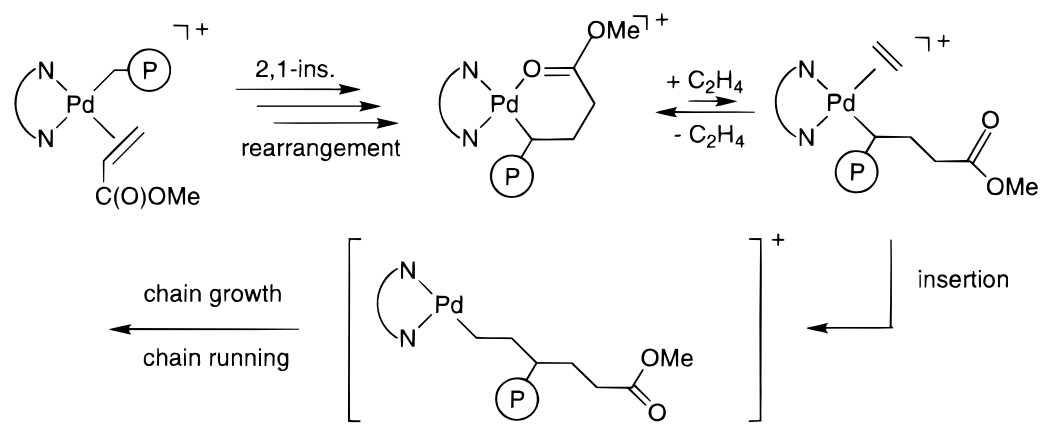

(P) $\equiv$ growing polymer chain

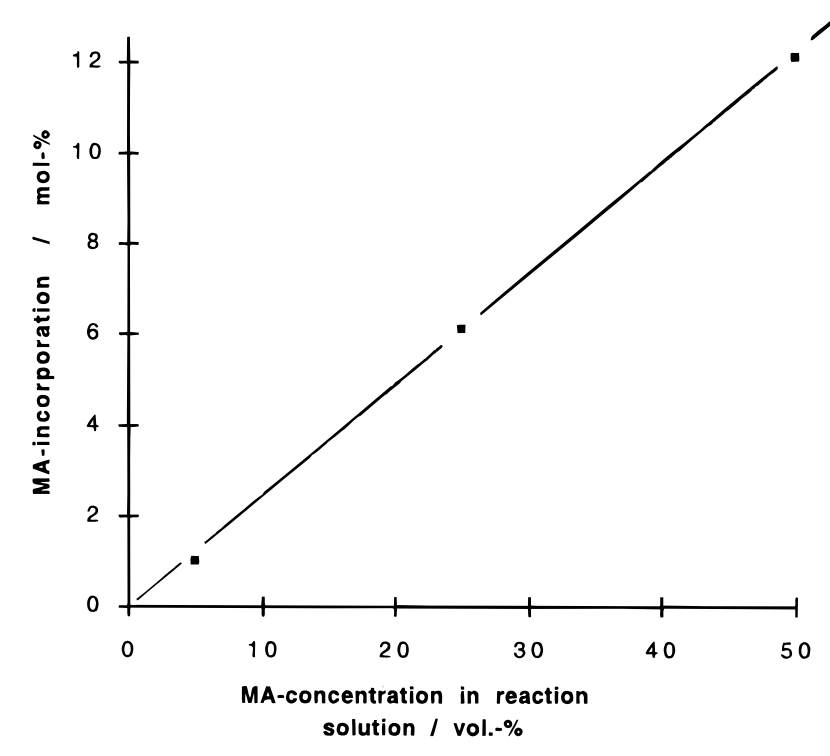

Figure 1. Linear dependence of MA incorporation on the MA concentration in the reaction solution.

Correspondingly, increasing the ethylene pressure results in an increase in ethylene and MA turnovers (Table 1, entry 4 vs 3). The monomer concentrations have no significant effect on the total number of methyl- and ester-ended branches for a given catalyst. The number of branches observed is similar to that for the corresponding ethylene homopolymers (entries 5-7). This suggests that chain-running (Scheme 2) is fast compared to chain growth in the case of the palladium catalysts. In all experiments given in Tables 1 and 2, the ester groups are predominantly located at the ends of branches with $x \geq 2$ (see eq 1). The average length of the ester-ended branch decreases with increasing ethylene pressure; that is, after an MA-insertion the resulting $\mathrm{Pd}-$ alkyl complex may be trapped prior to isomerization to a six-membered chelate or further chain running. ${ }^{17,23}$

Figures 2 and 3 show the progress of the copolymerization over time. Catalyst deactivation occurs within $50 \mathrm{~h}$ with the $\mathrm{ArN}=\mathrm{C}(\mathrm{Me})-\mathrm{C}(\mathrm{Me})=\mathrm{NAr}\left(\mathrm{Ar} \equiv 2,6-\mathrm{C}_{6} \mathrm{H}_{3}(i-\mathrm{Pr})_{2}\right)$ ligand $(\mathbf{b})$ (Figure 2), whereas for the catalyst with the corresponding 2,6dimethyl substituted ligand $\mathbf{d}$ (Figure 3), no loss in activity was observed for over 3 days. ${ }^{24,25}$ In both cases, varying the reaction

(23) The observation that chain running is fast relative to chain growth in general, whereas the intermediate formed after an MA-insertion may be trapped by ethylene, is in accord with the result that rearrangement of the chelate complexes (eq 1) is much slower than isomerization of an unsaturated or weakly ligated alkyl complex $\left[\left(\mathrm{N}^{\wedge} \mathrm{N}\right) \mathrm{PdR}(\mathrm{L})\right]^{+}(\mathrm{L} \equiv$ solvent; agostic interaction): Tempel, D. J.; Johnson, L. K.; Brookhart, M., unpublished results. time in the range of $24-72 \mathrm{~h}$ had little effect on polymer molecular weight. A run under identical conditions as entry 2 in Table $2(18 \mathrm{~h})$ terminated after $3 \mathrm{~h}$ yielded a polymer of 2 -fold lower molecular weight $\left(M_{\mathrm{n}}=23 \mathrm{~kg} / \mathrm{mol} ; 870 \mathrm{TO}\right)$. That is, in the $3 \mathrm{~h}$ experiment the rate of chain transfer is on the order of the reaction time, whereas in the longer experiments, the molecular weight is controlled by chain transfer and thus reflects the properties of the specific catalyst under steady state conditions of chain initiation and chain transfer. Assuming that the copolymerization is retarded by formation of a chelate as a stable catalyst resting state as discussed above, but with otherwise identical mechanisms of chain propagation and chain transfer operating as in the case of ethylene homopolymerization, one would expect the molecular weights of the copolymers to approach those of the homopolymers at sufficiently long reaction times. However, the molecular weights of the copolymers are much lower than those of ethylene homopolymers. Additional modes of chain transfer must be operative. Possibly, intermediates of the type $\left[\left(\mathrm{N}^{\wedge} \mathrm{N}\right) \mathrm{PdH}\{\mathrm{RCH}=\mathrm{CHC}(\mathrm{O}) \mathrm{OMe}\}\right]^{+}$are involved. It is interesting in this respect that for $\mathbf{2 c}$, a slow reaction with excess MA resulted in elimination of the chelate moiety and formation of a new chelate $\left[\left(\mathrm{N}^{\wedge} \mathrm{N}\right) \operatorname{Pd}\left\{\left(\mathrm{CH}_{2}\right)_{2} \mathrm{C}(\mathrm{O})\right.\right.$ $\mathrm{OMe}\}]^{+}$. In addition, exposure of $2 \mathrm{a}$ to 6000 equiv of MA for $18 \mathrm{~h}(0.02 \mathrm{mmol} ; 10 \mathrm{~mL}$ MA; $10 \mathrm{~mL}$ methylene chloride) resulted in decomposition of the complex and formation of a small amount of MA-dimers, predominantly dimethyl hex-3enedioate. In the absence of excess MA, 2a is stable in methylene chloride solution for days.

The mechanistic experiments depicted in eq 2 (vide infra) revealed that MA binds to the electrophilic metal center via its olefinic functionality (as opposed to coordination via its ester group). ${ }^{26}$ To further probe for solvent effects or other effects of the ester functionality of the MA monomer present in the copolymerization reactions, an ethylene homopolymerization was run in a 3:1 mixture (v:v) of methylene chloride and methyl propionate under conditions otherwise identical with entry 6 of Table 1. Productivity and polymer molecular weight are reduced (32000 TO; $M_{\mathrm{n}}=306 \mathrm{~kg} / \mathrm{mol}$ ), but compared to the copolymerization experiments the effect is small, and it can be concluded that the presence of ester groups in the reaction mixture does not significantly effect the outcome of polymerization experiments with these catalysts.

(24) The instability of complexes containing the 2,6-diisopropylsubstituted ligand as compared to the 2,6-dimethyl-substituted ligand may be related to the greater accessibility of the $\mathrm{C}-\mathrm{H}$ bond of the $i$-Pr substituent to the metal center. ${ }^{20}$

(25) In homopolymerizations using $\mathbf{2 d}$, turnover frequency in a $1 \mathrm{~h}$ experiment was the same as that in the $18.5 \mathrm{~h}$ experiment (entry 8 , Table 1) under identical conditions. This implies little or not catalyst deactivation over $18 \mathrm{~h}$. 
Table 2. Ethylene-MA Copolymerization: Effect of the $\alpha$-Diimine Ligand ${ }^{a}$

\begin{tabular}{|c|c|c|c|c|c|c|c|c|c|c|c|}
\hline \multirow[b]{3}{*}{ entry } & \multicolumn{3}{|c|}{ ligand } & \multicolumn{5}{|c|}{ results } & \multicolumn{3}{|c|}{ polymer properties } \\
\hline & & \multirow[b]{2}{*}{$-\mathrm{N}=\mathrm{C}(\mathbf{R})-$} & \multirow{2}{*}{$\begin{array}{l}\text { subst. of aryl } \\
\text { ring } \mathbf{A r}-\mathrm{N}=\end{array}$} & \multirow{2}{*}{$\begin{array}{l}\text { retn. } \\
\text { cond. }\end{array}$} & \multirow{2}{*}{$\begin{array}{l}\text { polymer } \\
\text { yield }(\mathrm{g})\end{array}$} & \multirow{2}{*}{$\begin{array}{c}\text { MA-incorp. }{ }^{b} \\
(\%)\end{array}$} & \multicolumn{2}{|c|}{$\mathrm{TON}^{d}$} & \multirow{2}{*}{$\begin{array}{c}M_{\mathrm{n}}{ }^{a} \\
\left(\times 10^{-3}\right)\end{array}$} & \multirow[b]{2}{*}{$M_{\mathrm{w}} / M_{\mathrm{n}}$} & \multirow{2}{*}{$\begin{array}{c}\text { branches } \\
1000 \mathrm{C}\end{array}$} \\
\hline & & & & & & & $\mathrm{E}$ & $\overline{\text { MA }}$ & & & \\
\hline 1 & $\mathbf{a}$ & $\mathrm{H}$ & $2,6-{ }^{i} \operatorname{Pr}_{2}$ & A & 1.2 & 5.0 & 355 & 19 & $0.3^{c}$ & & n.d. \\
\hline 2 & b & $\mathrm{Me}$ & 2,6- ${ }^{i} \mathrm{Pr}_{2}$ & A & 11.2 & 4.0 & 3560 & 148 & 42 & 1.8 & 97 \\
\hline 3 & $\mathbf{c}$ & An & $2,6-{ }^{i} \operatorname{Pr}_{2}$ & A & 1.2 & 4.7 & 364 & 18 & 10 & 1.8 & 109 \\
\hline 4 & d & $\mathrm{Me}$ & $2,6-\mathrm{Me}_{2}$ & A & 2.3 & 14.2 & 542 & 90 & 7 & 2.1 & 116 \\
\hline 5 & b & $\mathrm{Me}$ & $2,6-{ }^{i} \mathrm{Pr}_{2}$ & B & 8.5 & 7 & 827 & 58 & 17 & 1.4 & 128 \\
\hline 6 & & $\mathrm{Me}$ & $2-{ }^{i} \operatorname{Pr} 6-\mathrm{Me}$ & $\mathrm{B}$ & 4.0 & 15 & 283 & 50 & 12 & 1.3 & 170 \\
\hline 7 & d & $\mathrm{Me}$ & $2,6-\mathrm{Me}_{2}$ & B & 2.5 & 20 & 154 & 41 & 8 & 1.4 & 203 \\
\hline 8 & & $\mathrm{Me}$ & $2,4,6-\mathrm{Me}_{3}$ & B & 3.0 & 25 & 162 & 54 & 8 & 1.4 & 255 \\
\hline 9 & & $\mathrm{Me}$ & 2,6- $\mathrm{Me}_{2} 4-\mathrm{Br}$ & $\mathrm{B}$ & 3.6 & 15 & 266 & 47 & 7 & 1.4 & 178 \\
\hline
\end{tabular}

${ }^{a}$ Determined by GPC vs polystyrene standards, uncorrected. ${ }^{b} \mathrm{Mol} \% .{ }^{c}$ Determined by ${ }^{1} \mathrm{H}$ NMR spectroscopy of the nonvolatile product fraction; ca. $0.5 \mathrm{~g}$ of volatile products were formed additionally. ${ }^{d}$ Turnover number $\equiv$ mole substrate converted per mole catalyst. ${ }^{e}$ Reaction conditions A: $0.1 \mathrm{mmol}$ catalyst precursor 2; solvent: $50 \mathrm{~mL}$ of $\mathrm{CH}_{2} \mathrm{Cl}_{2} ; 50 \mathrm{~mL}$ of MA ( $\equiv 6 \mathrm{M}$ ); $6 \mathrm{~atm}$ (i.e., $5 \mathrm{atmg}$ ); temperature: $35^{\circ} \mathrm{C}$; reaction time: 18.5 h. B: $0.3 \mathrm{mmol}$ catalyst precursor 3; solvent: $40 \mathrm{~mL} \mathrm{CH}_{2} \mathrm{Cl}_{2} ; 5 \mathrm{~mL} \mathrm{MA}(\equiv 1.2 \mathrm{M}) ; 1 \mathrm{~atm}$ (ambient pressure); temperature: $25^{\circ} \mathrm{C}$; reaction time: $72 \mathrm{~h}$.

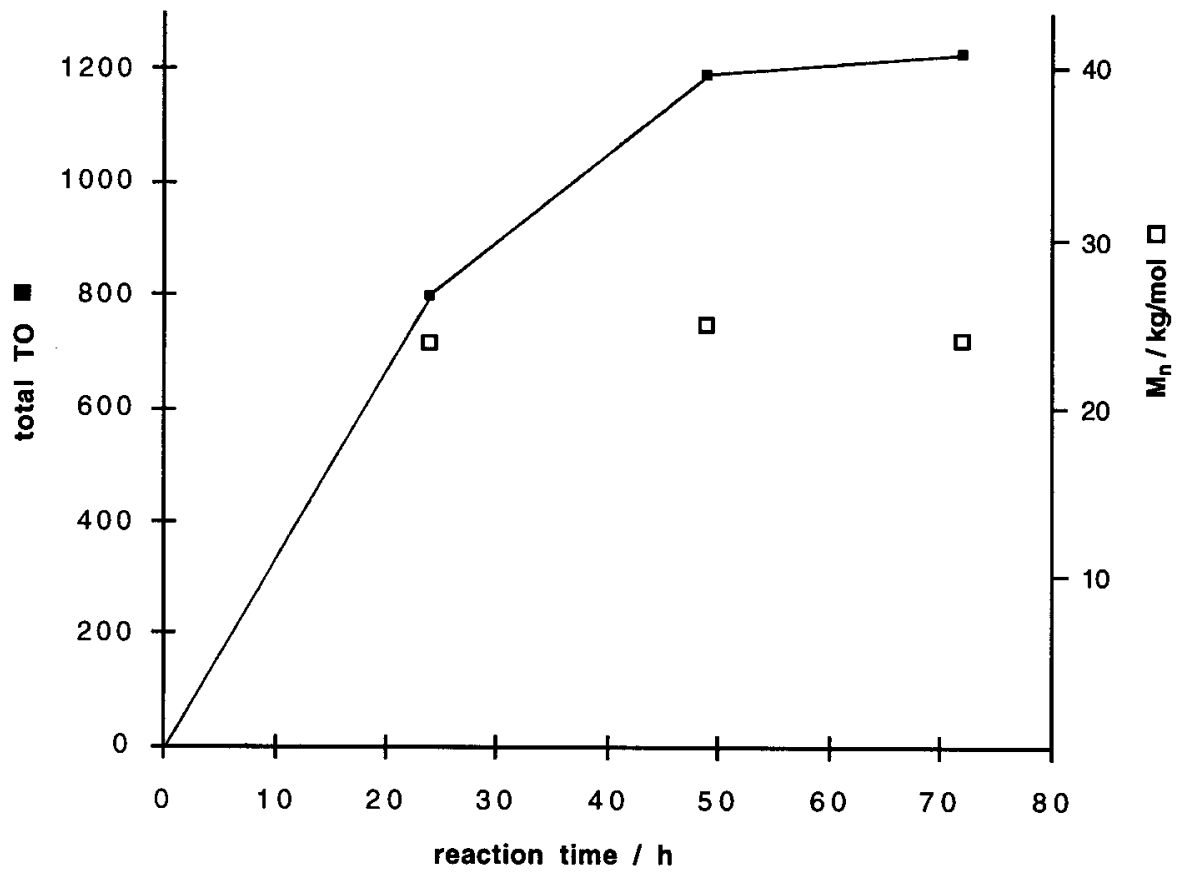

Figure 2. Reaction profile of ethylene-MA copolymerization employing ligand $\mathrm{ArN}=\mathrm{C}(\mathrm{Me})-\mathrm{C}(\mathrm{Me})=\mathrm{NAr}\left(\mathrm{Ar} \equiv 2,6-\mathrm{C}_{6} \mathrm{H}_{3}(i-\mathrm{Pr})_{2}\right)(\mathbf{b})$. $\mathrm{Reaction}$ conditions of entry 5 , Table 2 .

Table 2 shows the effects of variations of ligand structure on the copolymerizations. Variation of the diimine backbone substituents $\mathrm{R}$ does not significantly affect the percentage of

(26) (a) To convert 1a completely to 5a in a reasonable time at temperatures low enough to prevent migratory insertion, an excess of MA was utilized. This results in formation of an additional species, identified as the MA adduct of $\mathbf{6 a}, \quad\left[\left(\mathrm{N}^{\wedge} \mathrm{N}\right) \mathrm{Pd}\{\mathrm{CH}(\mathrm{Et}) \mathrm{C}(\mathrm{O}) \mathrm{OMe}\}\right.$ $\left.\left\{\mathrm{H}_{2} \mathrm{C}=\mathrm{CHC}(\mathrm{O}) \mathrm{OMe}\right\}\right]^{+}$(t at $\delta 0.53, J=7 \mathrm{~Hz}\left(\mathrm{CD}_{2} \mathrm{Cl}_{2},-62{ }^{\circ} \mathrm{C}\right)$ ). This does not effect the rate of migratory insertion, which was found to be independent of [MA] in the range of 1.3-18 equiv MA in the limit of error. Some subsequent rearrangement of $6 \mathbf{a}$ to $7 \mathbf{a}$ also occurred. (b) Starting from $\mathbf{1 b}$, displacement of ether by MA occurs more slowly than with 1a and thus interferes with observation of the migratory insertion. Therefore, complexes of ligand a were preferred for mechanistic studies. In addition to the $\eta^{2}$-olefin complex $\mathbf{5 b}\left({ }^{1} \mathrm{H}\right.$ NMR $\left(\mathrm{CD}_{2} \mathrm{Cl}_{2},-71{ }^{\circ} \mathrm{C}\right) \delta 5.01(\mathrm{~d}, 1, J=$

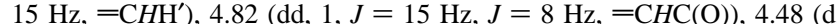
$\left.1, J=8 \mathrm{~Hz},=\mathrm{CH} H^{\prime}\right), 3.60(\mathrm{~s}, 3 ; \mathrm{OMe}), 2.38$ and 2.27 (s, 3 each; $\mathrm{N}=\mathrm{C}-$ $\left.\left.(M e)-\mathrm{C}^{\prime}(M e)=\mathrm{N}\right), 0.32(\mathrm{~s}, 3 ; \mathrm{PdMe})\right)$, a second species $5 \mathbf{b}^{\prime}$ with $\delta 2.96(\mathrm{~s}$, 3, OMe), $2.18\left(\mathrm{~s}, 6, \mathrm{~N}=\mathrm{C}(M e)-\mathrm{C}^{\prime}(M e)=\mathrm{N}\right), 0.26$ (s, 3H.; $\left.\mathrm{PdMe}\right)\left(\mathrm{CD}_{2} \mathrm{Cl}_{2}\right.$, $\left.-71{ }^{\circ} \mathrm{C}\right)$ is observed. The latter is assigned as the $\kappa$-O complex analogous to $\mathbf{5 b}$, in which the MA-ligand is bound via its carbonyl group. At $-71^{\circ} \mathrm{C}$, conversion of $\mathbf{5} \mathbf{b}^{\prime}$ to $\mathbf{5 b}$ was observed (in addition to migratory insertion), This rearrangement presumably occurs very rapidly at room temperature, so that coordination of the acrylate via the carbonyl-group is relatively insignificant in typical copolymerization experiments. acrylate incorporation in the copolymer (Table 2, entries 1-3). However, the nature of $\mathrm{R}$ affects productivities $(\mathrm{Me}>\mathrm{An} \approx$ $\mathrm{H})$ and molecular weights $(\mathrm{Me}>\mathrm{An}>\mathrm{H})$, and the trends follow those observed for the ethylene homopolymerizations. ${ }^{14}$ Reduction of the steric bulk of the substituents on the aryl moieties $R^{\prime}$ results in an increase of the relative acrylate incorporation, presumably due to the greater accessibility of the metal center for the binding of the sterically larger olefin (Table 2 , entry 2 vs 4 and 5-7). However, at the same time, less effective retardation of associative olefin exchange enhances chain transfer and thus lowers the molar mass of the copolymer.

Interpretation of the relative catalyst activities is complex: mechanistic experiments (vide infra) suggest that opening of a chelate complex by ethylene coordination, believed in part to control the TO frequency of the copolymerization reaction, is favored by smaller diimine substituents $\mathrm{R}^{\prime}$. On the other hand, the smaller diimine substituents also result in lower catalyst activity in ethylene homopolymerization experiments due to slower chain growth (entry 6 vs 8 in Table 1). For example, for the production of a copolymer of given MA incorporation 


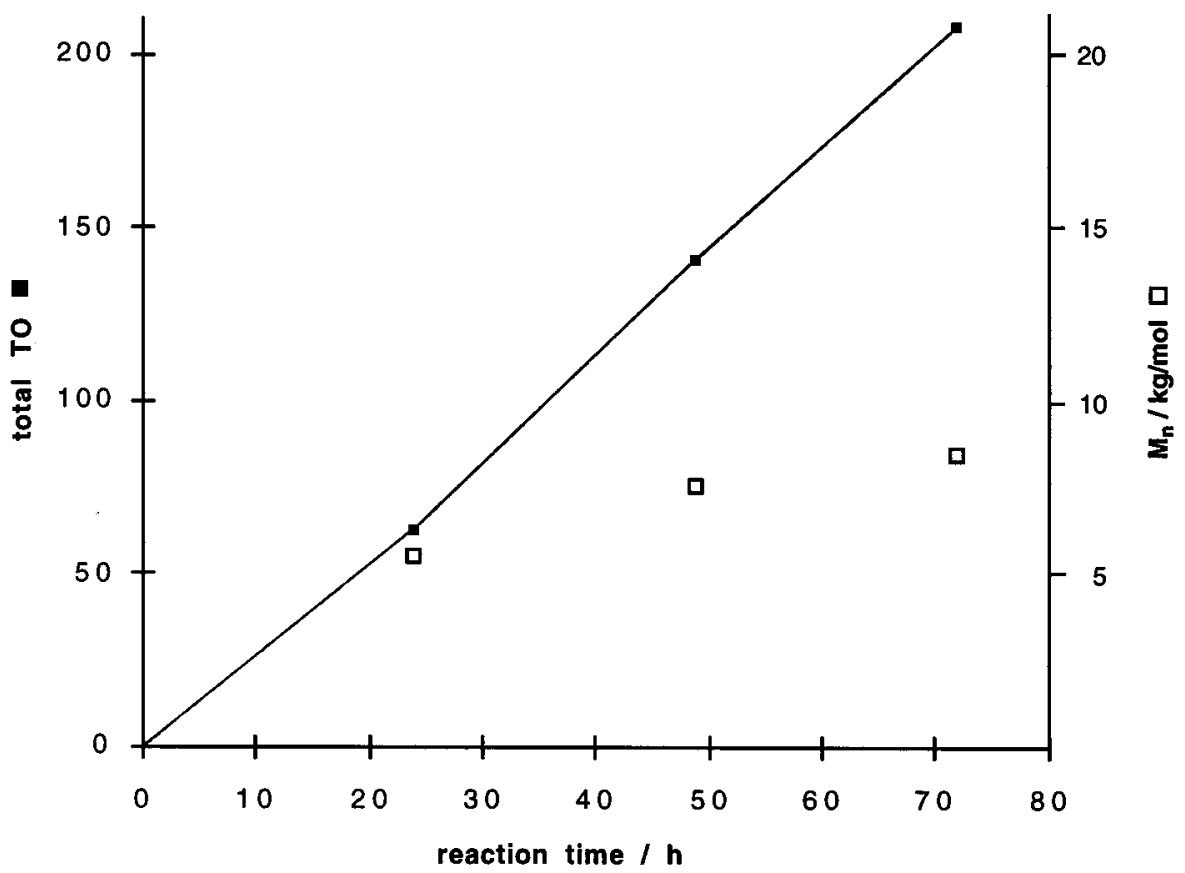

Figure 3. Reaction profile of ethylene-MA copolymerization employing ligand $\left.\mathrm{ArN}=\mathrm{C}(\mathrm{Me})-\mathrm{C}(\mathrm{Me})=\mathrm{NAr}\left(\mathrm{Ar} \equiv 2,6-\mathrm{C}_{6} \mathrm{H}_{3} \mathrm{Me}\right)_{2}\right)(\mathbf{d}) . \mathrm{Reaction}$ conditions of entry 7 , Table 2 .

Table 3. $\alpha$-Olefin-MA Copolymerizations ${ }^{c}$

\begin{tabular}{|c|c|c|c|c|c|c|c|c|c|c|c|c|}
\hline \multirow[b]{3}{*}{ entry } & \multirow[b]{3}{*}{$\alpha$-olefin } & \multirow[b]{3}{*}{ catalyst } & \multicolumn{3}{|c|}{ retn. cond. } & \multicolumn{4}{|c|}{ results } & \multicolumn{3}{|c|}{ polymer properties } \\
\hline & & & \multirow{2}{*}{$\begin{array}{l}\text { reaction } \\
\text { time (h) }\end{array}$} & \multirow{2}{*}{$\begin{array}{c}\text { conc. } \\
\alpha \text {-olefin }\end{array}$} & \multirow{2}{*}{$\begin{array}{l}\text { conc. } \\
\text { MA (m) }\end{array}$} & \multirow{2}{*}{$\begin{array}{l}\text { polymer } \\
\text { yield }(\mathrm{g})\end{array}$} & \multirow{2}{*}{$\begin{array}{c}\text { MA-incorp. }{ }^{b} \\
(\%)\end{array}$} & \multicolumn{2}{|c|}{ TON } & \multirow{2}{*}{$\begin{array}{c}M_{\mathrm{n}}{ }^{a} \\
\left(\times 10^{-3}\right)\end{array}$} & \multirow[b]{2}{*}{$M_{\mathrm{w}} / M_{\mathrm{n}}$} & \multirow{2}{*}{$\begin{array}{c}\text { branches/ } \\
1000 \mathrm{C}\end{array}$} \\
\hline & & & & & & & & $\alpha$-olefin & MA & & & \\
\hline 1 & propene & $2 b$ & 18.5 & $6 \mathrm{~atm}$ & 0.6 & 5.0 & 1.1 & 1179 & 13 & 37 & 1.8 & 213 \\
\hline 2 & hexene & $4 b$ & 18.5 & $1.6 \mathrm{M}$ & 1.2 & 0.92 & 10.3 & 187 & 22 & 24 & 1.6 & 91 \\
\hline 3 & hexene & $4 b$ & 39 & $1.6 \mathrm{M}$ & 1.2 & 1.53 & 11.4 & 313 & 40 & 30 & 1.9 & 94 \\
\hline 4 & dodecene & $4 \mathrm{~b}$ & 18.5 & $1.6 \mathrm{M}$ & 1.2 & 1.39 & 11.8 & 157 & 21 & 46 & 1.4 & 52 \\
\hline 5 & hexene & $2 d$ & 18.5 & $1.7 \mathrm{M}$ & 1.1 & 1.43 & 20.3 & 343 & 87 & 26 & 1.5 & 88 \\
\hline
\end{tabular}

${ }^{a}$ Determined by GPC vs polystyrene standards, uncorrected. ${ }^{b} \mathrm{Mol} \% .{ }^{c}$ Reaction conditions: $0.05 \mathrm{mmol}$ catalyst precursor (entry 1 : $0.1 \mathrm{mmol}$, entry 5: $0.039 \mathrm{mmol}$ ); solvent: $\mathrm{CH}_{2} \mathrm{Cl}_{2}$ (total volume solvent and monomers: $50 \mathrm{~mL}$, entry 1: $100 \mathrm{~mL}$ ); temperature: $25^{\circ} \mathrm{C}\left(\mathrm{entry} 1: 35^{\circ} \mathrm{C}\right.$ ).

by catalyst $\mathbf{2 b}\left(\mathrm{R}^{\prime}=i\right.$-Pr) and catalyst $\mathbf{2 d}\left(\mathrm{R}^{\prime}=\mathrm{Me}\right)$, a similar rate was observed with both catalysts (entry 3 of Table 1 vs entry 4 of Table 2). Electron-releasing or -withdrawing substituents were introduced in the $p$-position of the aryl ring (entries 7-9 of Table 2). With more electron-rich ligands, a higher acrylate incorporation is observed. ${ }^{27}$ Presumably, binding of the electron-deficient olefin relative to ethylene is increased by decreasing the electrophilicity of the metal center. Again, interpretation of the relative activities is not straightforward.

2. Copolymerization of $\alpha$-Olefins with Acrylates. The cationic palladium diimine catalysts are also effective for the copolymerization of $\alpha$-olefins with functionalized olefins (Table 3 ). The NMR spectra of the copolymers show that they possess structures similar to the ethylene copolymers with respect to the predominant location of ester groups at the ends of branches. ${ }^{17}$ As is the case for the $\alpha$-olefin homopolymers, ${ }^{14,17}$ the total branching is lower than would be expected for an exclusive incorporation of the $\alpha$-olefin in a 1,2 -fashion. This implies that a significant amount of 2,1-insertion occurs, followed by "chain straightening" by migration of the metal center to the terminal carbon atom. With long chain $\alpha$-olefins such as dodecene (entry 4), this enables the production of

(27) This appears to be a general trend, as a decrease in MA incorporation upon placing electron-withdrawing chloro substituents in the meta and ortho positions and an increase in MA incorporation upon placing donating $o$-methoxy substituents on other series of $N$-aryl-substituted $\alpha$-diimine ligands have been observed: Wang, Y.; Wang, L.; Johnson, L. K., unpublished results. copolymers with lower branching and different properties than are accessible by ethylene copolymerization. For example, the dodecene-MA copolymer from entry 4 has 52 branches per 1000 carbon atoms versus typically 100 branches for an ethyleneMA copolymer.

Comparing the catalyst activity of $\alpha$-olefin versus ethylene copolymerizations for a polymer of a given molar acrylate incorporation, the $\alpha$-olefin copolymerizations are less productive (entry 3, Table 1 vs entry 2, Table 3 ). In terms of the assumed mechanism, formation of chelate complexes is expected to have an even greater retarding effect in copolymerizations with $\alpha$-olefins than with ethylene, as mechanistic experiments show that displacement of the chelating carbonyl group is less effective with $\alpha$-olefins (vide infra). Also, the lower rate of migratory insertion of $\alpha$-olefins in comparison to ethylene will result in a lower polymerization rate. ${ }^{28}$

While under the same reaction conditions the $\alpha$-olefin copolymerization rates are lower than the ethylene copolymerization rates, the relative percent acrylate incorporation is higher. For example, the hexene-MA copolymerizations give a relative incorporation of 7:1 of hexene to MA at equal molar concentrations of the monomers, whereas for ethylene-MA it is ca. 150: 1. The higher incorporation of MA in the $\alpha$-olefin copolymers is the result of two factors: (a) the rates of olefin insertion into

(28) Migratory insertion of propene into a Pd-alkyl bond was found to be ca. 3 -fold slower than insertion of ethylene in complexes $\left[\left(\mathrm{N}^{\wedge} \mathrm{N}\right) \mathrm{PdR}\right.$ (olefin) $]^{+} .14$ 

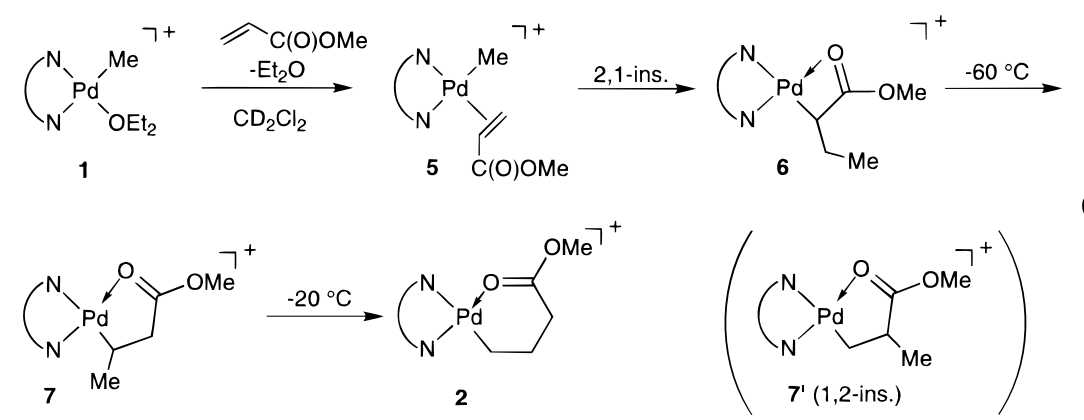

(2)

a growing polymer chain are lower for $\alpha$-olefins than for ethylene, ${ }^{28}$ and (b) the difference in relative binding is smaller between $\alpha$-olefins and MA than between ethylene and MA, although in both cases the acrylate binding is weaker (vide infra).

The effects of variations in ligand structure were examined in the $\alpha$-olefin copolymerizations. As in ethylene-MA copolymerizations, under identical reaction conditions a much higher acrylate incorporation is observed in hexene-MA copolymerization with the less bulky substituted ligand $\mathbf{d}\left(\mathrm{R}^{\prime} \equiv \mathrm{Me}\right)$ than with its isopropyl-substituted analogue $\mathbf{b}$ (entry 2 vs 5, Table 3 ). At the same time, the polymer yield with $\mathbf{d}$ is lower than with $\mathbf{b}$ in the ethylene-MA copolymerization, due to pronounced rate-inhibiting chelate formation with the increased percentage of acrylate insertions with d (entry 2 vs 4, Table 2). For synthesis of an ethylene-MA copolymer of given acrylate incorporation, similar productivities are observed with both ligands; the lower rate of olefin migratory insertion with $\mathbf{d}$ is apparently compensated by more facile chelate opening (entry 4, Table 2 vs entry 3, Table 1). In contrast, in hexene-MA copolymerizations similar productivities are observed with $\mathbf{b}$ and $\mathbf{d}$ under identical reaction conditions, despite the much higher MA incorporation with d. Mechanistic experiments (vide infra) suggest that in addition to chelate opening by olefins generally being more facile with $\mathbf{d}$ in comparison to $\mathbf{b}$, chelateopening by an $\alpha$-olefin in comparison to opening by ethylene is more favorable with $\mathbf{d}$.

B. Mechanistic Studies. Low-temperature NMR experiments (eq 2) showed that the $\pi$-olefin complex $\mathbf{5 a}$, formed upon reacting the ether-adduct $\mathbf{1 a}$ with $\mathrm{MA}$, undergoes migratory insertion in a 2,1-mode with ca. 95\% regioselectivity to yield 6a. Subsequent isomerization via 7a yields the six-membered chelate $\mathbf{2} \mathbf{a}$ as the final, stable product. Only minor amounts of the 1,2-insertion product $\mathbf{7}^{\prime} \mathbf{a}$ are formed. ${ }^{29,30}$

In the copolymerization reaction, the relative incorporations of the comonomers are determined by their relative insertion rates and by their relative binding affinities to the metal center. These factors were investigated by low-temperature NMR spectroscopy using the methyl complexes $\left[\left(\mathrm{N}^{\wedge} \mathrm{N}\right) \mathrm{PdMe}(\text { olefin })\right]^{+}$ as model compounds.

1. Olefin Insertion Rates. The rate of migratory insertion of MA into the $\mathrm{Pd}-\mathrm{Me}$ bond of $\mathbf{5 a}$ to form $\mathbf{6 a}$ was followed by ${ }^{1} \mathrm{H}$ NMR spectroscopy at -75 to $-62{ }^{\circ} \mathrm{C}$. An Eyring plot of rate data obtained (Figure 4) gave $\Delta H^{\ddagger}=12.1 \pm 1.4 \mathrm{kcal} /$ mol, $\Delta S^{\ddagger}=-14.1 \pm 7.0$ eu. ${ }^{26}$ We previously reported data for olefin migratory insertion in the corresponding ethylene complexes. ${ }^{14}$ In this case, the rates of subsequent ethylene insertions into the growing polymer chain could also be monitored by NMR spectroscopy and did not differ significantly from the rate of the first insertion of ethylene into the $\mathrm{Pd}-\mathrm{Me}$ bond. Extrapolation of these data to room temperature is in good agreement with the highest activities observed in ethylene homopolymerization experiments (for $\mathbf{2 b}$ as catalyst precursor: $k=1.2 \mathrm{~s}^{-1}$ at $25^{\circ} \mathrm{C}, \Delta G^{\ddagger}=17.4 \mathrm{kcal} / \mathrm{mol}$ for conditions of entry 6 Table

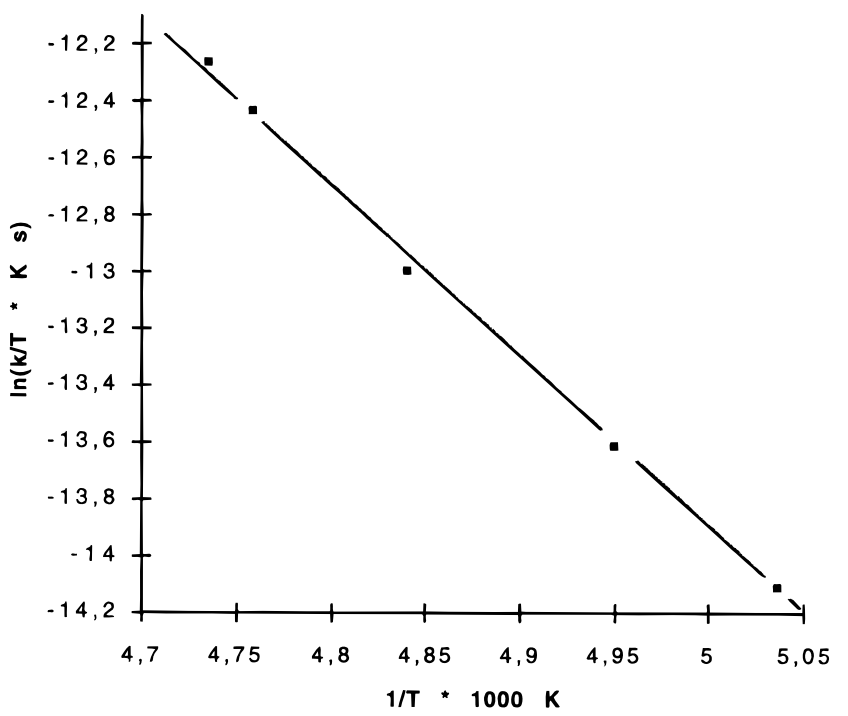

Figure 4. Eyring plot for migratory insertion of MA in 5a.

$1,1 \mathrm{~h}$ reaction time, 6 atm versus $\Delta G^{\ddagger}\left(25^{\circ} \mathrm{C}\right)=17.5 \mathrm{kcal} / \mathrm{mol}$ as extrapolated from the low-temperature experiments). Given these results, it is reasonable to use the insertion of MA into a $\mathrm{Pd}-\mathrm{Me}$ bond as a model for migratory insertion of MA into the growing polymer chain.

2. Relative Binding Constants. The equilibrium constants for the reaction depicted in eq 3 were determined for a variety of ligands $L$ and $L^{\prime}$. Results are summarized in Table $4 .^{31}$ The relative trend in binding strength observed is ethylene > $\alpha$-olefins $\gg$ acrylates. $^{26 \mathrm{~b}}$

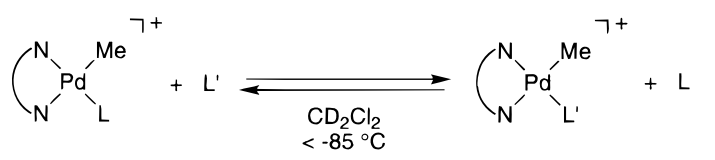

The electron-deficient olefin MA binds so much more weakly to the electrophilic metal center than ethylene that this equilibrium constant could not be determined in a single pairwise competition experiment. 4-Methoxystyrene was found to be a suitable ligand of intermediate coordination strength. The relative binding constant of ethylene vs propylene is similar to that reported by Kurosawa et al. for $\left[\left(\mathrm{C}_{5} \mathrm{H}_{5}\right) \mathrm{Pd}\left(\mathrm{PPh}_{3}\right)(\right.$ olefin $\left.)\right]-$

(29) The 2,1-insertion mode is normally observed for polar olefins. See, for example: (a) Ozawa, F.; Hayashi, T.; Koide, H.; Yamamoto, A. J. Chem. Soc., Chem. Commun. 1991, 1469-1470. (b) Hauptman, E.; Brookhart, M.; Fagan, P. J.; Calabrese, J. C. Organometallics 1994, 13, 774-780.

(30) The percentage of the 2,1-insertion product formed decreases with increased size of the backbone substituent $(\mathrm{R})$ and particularly with increased bulk of the acrylate substituent. For example, for the insertion of tertbutylacrylate $\left(\mathrm{R}=\mathrm{Me}, \mathrm{R}^{\prime}=i\right.$-Pr), the regioselectivity of the insertion was reversed with $63 \%$ of the product consisting of the 1,2-insertion product. ${ }^{15}$

(31) For relative binding constants of other ligands in similar phenanthroline complexes, cf.: Rix, F. C.; Brookhart, M.; White, P. S. J. Am. Chem. Soc. 1996, 118, 4746-4764. 
Table 4. Equilibrium Constants for $\left[\left(\mathrm{N}^{\wedge} \mathrm{N}\right) \mathrm{PdMe}(\mathrm{L})\right]^{+}+\mathrm{L}^{\prime} \rightleftarrows\left[\left(\mathrm{N}^{\wedge} \mathrm{N}\right) \operatorname{PdMe}\left(\mathrm{L}^{\prime}\right)\right]^{+}+\mathrm{L}\left(\mathrm{N}^{\wedge} \mathrm{N} \equiv \operatorname{ArN}=\mathrm{C}(\mathrm{H})-\mathrm{C}(\mathrm{H})=\mathrm{NAr}, \mathrm{Ar} \equiv 2,6--^{i} \mathrm{Pr}{ }_{2} \mathrm{C}_{6} \mathrm{H}_{3}\right.$ $(\mathbf{a}))^{b}$

\begin{tabular}{|c|c|c|c|c|}
\hline $\mathrm{L}$ & $\mathrm{L}^{\prime}$ & $T\left({ }^{\circ} \mathrm{C}\right)$ & $K_{\mathrm{eq}}$ & $\Delta G(\mathrm{kcal} / \mathrm{mol})$ \\
\hline ethylene & 4-methoxystyrene & -95 & $(5.8 \pm 1.2) \times 10^{-3}$ & $1.8 \pm 0.1$ \\
\hline 4-methoxystyrene & MA & -95 & $(1.8 \pm 0.4) \times 10^{-4}$ & $3.1 \pm 0.1$ \\
\hline ethylene & MA & -95 & $(1.0 \pm 0.3) \times 10^{-6 a}$ & $4.9 \pm 0.2^{a}$ \\
\hline ethylene & propene & -85 & $(9.3 \pm 1.9) \times 10^{-2}$ & $0.9 \pm 0.1$ \\
\hline ethylene & hexene & -85 & $(4.3 \pm 0.9) \times 10^{-1}$ & $0.3 \pm 0.1$ \\
\hline
\end{tabular}

${ }^{a}$ Calculated from $K_{\text {eq }}$ (ethylene vs 4-methoxystyrene) and $K_{\mathrm{eq}}\left(4\right.$-methoxystyrene vs MA). ${ }^{b}$ Determined by ${ }^{1} \mathrm{H} \mathrm{NMR}$. Solvent: $\mathrm{CD}_{2} \mathrm{Cl}_{2}$.

Scheme 4

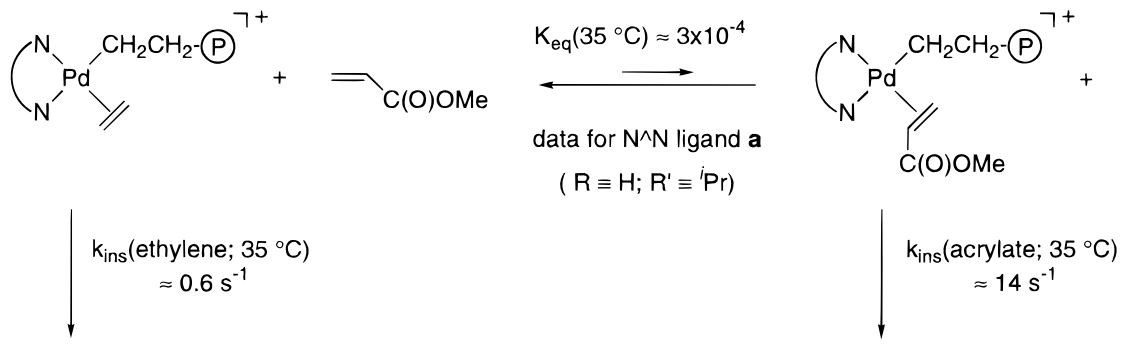

$$
\frac{\text { acrylate incorp. }}{\text { ethylene incorp. }}=\frac{\mathrm{K}_{\mathrm{eq}} \bullet \mathrm{k}_{\text {ins }}(\text { acrylate }) \cdot[\mathrm{MA}]}{\mathrm{k}_{\text {ins }}(\text { ethylene }) \cdot[\text { ethylene }]}
$$

Table 5. Thermodynamic Data for Equilibria $2+\mathrm{C}_{2} \mathrm{H}_{4} \rightleftarrows \mathbf{1 0}\left(\mathrm{R}^{\prime \prime}\right.$ $\equiv \mathrm{H})^{b}$

\begin{tabular}{cccc}
\hline complex & $\Delta H^{\circ}(\mathrm{kcal} / \mathrm{mol})$ & $\Delta S^{\circ}(\mathrm{eu})$ & $K_{\mathrm{eq}}\left(35^{\circ} \mathrm{C}\right)^{a}$ \\
\hline 2a & $-8.1 \pm 0.2$ & $-34 \pm 1$ & $2 \times 10^{-2}$ \\
2b & $-5.3 \pm 0.3$ & $-31 \pm 2$ & $1 \times 10^{-3}$ \\
2c & $-5.7 \pm 0.1$ & $-27 \pm 1$ & $1 \times 10^{-2}$ \\
2d & $-6.7 \pm 0.3$ & $-29 \pm 1$ & $3 \times 10^{-2}$ \\
\hline
\end{tabular}

${ }^{a}$ Extrapolated. ${ }^{b}$ Determined by ${ }^{1} \mathrm{H}$ NMR at -100 to $-58{ }^{\circ} \mathrm{C}$. Solvent: $\mathrm{CD}_{2} \mathrm{Cl}_{2}$.

$\mathrm{ClO}_{4}{ }^{32}$ Surprisingly, 1-hexene binds more strongly than propylene, and it must be assumed that the higher steric demand is overridden by electronic factors. Considering the use of nitrile complexes as catalyst precursors, it was found that nitriles are of similar coordination strength as olefins. For $\mathbf{3 b}+\mathrm{C}_{2} \mathrm{H}_{4} \rightleftharpoons$ $\mathbf{8 b}+\mathrm{CH}_{3} \mathrm{CN}$ (eq 3, $\mathrm{L}^{\prime} \equiv$ ethylene, $\mathrm{L} \equiv \mathrm{CH}_{3} \mathrm{CN}, \mathrm{CD}_{2} \mathrm{Cl}_{2}$ solvent $), K_{\text {eq }}\left(-85^{\circ} \mathrm{C}\right)=(4.6 \pm 0.9) \times 10^{-2}, \Delta G^{\circ}=1.2 \pm 0.1$ $\mathrm{kcal} / \mathrm{mol}$ was determined. Comparing 3,5-bis(trifluoromethyl)benzonitrile with acetonitrile, the aromatic nitrile was found to bind 10 -fold less strongly at room temperature $\left(\mathrm{CD}_{2} \mathrm{Cl}_{2}\right)$. Due to the large excess of monomers present in polymerization reactions, the equivalent of nitrile introduced with the catalyst precursor should have at most a slightly inhibiting effect in the copolymerization experiments.

Extrapolating the above data to the conditions of the copolymerization reaction $\left(35^{\circ} \mathrm{C}\right)$, the overall picture shown in Scheme 4 is obtained. ${ }^{33}$ Applying the equation depicted in Scheme 4 to the conditions of entry 1 in Table 2 (i.e., [MA] $=$ $6 \mathrm{~mol} / \mathrm{L}$, [ethylene] $=1 \mathrm{~mol} / \mathrm{L}$ ), an acrylate incorporation of 4 mol $\%$ is calculated, which matches reasonably well with the $5.0 \mathrm{~mol} \%$ observed. This agreement supports the applicability of the low-temperature NMR studies in modeling the copolymerization reaction. Thus, further studies may provide a detailed understanding of how the structure of the diimine ligand influences the properties and performance of the catalyst.

(32) Kurosawa, H.; Majima, T.; Asada, N. J. Am. Chem. Soc. 1980, 102, 6996-7003.

(33) The rate of ethylene insertion was obtained from a $1 \mathrm{~h}$ homopolymerization experiment (conditions of Table 1 entries 5-8, 2a, 29 atm).
3. Chelate Opening. As models for the presumed catalyst resting state, the reversible substitution of the chelating carbonyl group in $\mathbf{2 a}-\mathbf{c}$ by ethylene was investigated by low-temperature NMR spectroscopy (eq 4). Study of the temperature dependence of the equilibria $\mathbf{2}+\mathrm{C}_{2} \mathrm{H}_{4} \rightleftharpoons \mathbf{1 0}\left(\mathrm{R}^{\prime \prime} \equiv \mathrm{H}\right)$ provided the thermodynamic data given in Table 5 .

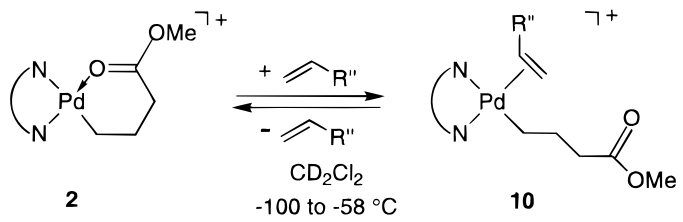

Extrapolation shows that at room-temperature chelating coordination of the carbonyl group is favored over ethylene binding in all cases for the methyl acrylate chelate complexes. ${ }^{34}$ For example, the equilibrium constant $K_{\text {eq }}$ for $\mathbf{2 b}+\mathrm{C}_{2} \mathrm{H}_{4} \rightleftharpoons$ $\mathbf{1 0 b}\left(\mathrm{R}^{\prime \prime} \equiv \mathrm{H}\right)$ given in Table 5 corresponds to a ratio of $\mathbf{2 b} /$ 10b of 1000:1 under typical reaction conditions of the copolymerization experiments (6 atm ethylene). Replacement of $\mathrm{R}^{\prime} \equiv{ }^{i}$ Pr by less bulky methyl groups ( $\mathbf{2 d}$ vs $\mathbf{2 b}$ ) results in more facile ethylene coordination. Thus under 6 atm of ethylene, the ratio of $\mathbf{2 d} / \mathbf{1 0 d}$ is $30: 1$ at $35^{\circ} \mathrm{C}$.

Chelate opening with $\alpha$-olefins is even less favorable than with ethylene. The large excess of olefin required affects the quality of the ${ }^{1} \mathrm{H}$ NMR spectra; thus no thermodynamic data was obtained, and only approximate values of equilibrium constants are reported. For propylene, $K_{\text {eq }}\left(-99^{\circ} \mathrm{C}\right) \approx 1 \mathrm{~L} / \mathrm{mol}$ was determined for $\mathbf{2 a}+\mathrm{C}_{3} \mathrm{H}_{6} \rightleftharpoons \mathbf{1 0 a}\left(\mathrm{R}^{\prime \prime} \equiv \mathrm{Me}\right)$, and for 1 -hexene $K_{\text {eq }}\left(-99^{\circ} \mathrm{C}\right) \approx 2 \mathrm{~L} / \mathrm{mol}\left(\mathrm{R}^{\prime \prime} \equiv \mathrm{C}_{4} \mathrm{H}_{9}\right)$. Compared to the equilibrium constant of ethylene at the same temperature, $K_{\text {eq }}(\alpha$-olefin $) / K_{\text {eq }}$ (ethylene) is ca. 0.003. As in the case of

(34) Chelate opening can be facilitated by the placement of electronwithdrawing substituents on the chelate complex. For example, the insertion of fluorinated octyl acrylate [FOA, $\left(\mathrm{H}_{2} \mathrm{C}=\mathrm{CHC}(\mathrm{O}) \mathrm{OCH}_{2}\left(\mathrm{CF}_{2}\right)_{6} \mathrm{CF}_{3}\right.$ ] yields an isolable chelate complex. The ring-opened form of the FOA chelate complex 10a can be observed at $-30{ }^{\circ} \mathrm{C}$, a temperature at which ethylene insertion readily occurs. Consequently, productivities in ethylene/FOA copolymerizations are comparable to ethylene homopolymerization reactions: (a) Reference 15. (b) Brookhart, M. S.; Johnson, L. K., Wang, L., unpublished results. 
ethylene, $\alpha$-olefin coordination becomes more facile with less bulky methyl substituents on the aryl ring. With 1-hexene, $K_{\mathrm{eq}}\left(-95^{\circ} \mathrm{C}\right) \approx 7 \mathrm{~L} / \mathrm{mol}$ was determined for $\mathbf{2 d}+\mathrm{C}_{6} \mathrm{H}_{12} \rightleftharpoons$ 10d $\left(\mathrm{R}^{\prime \prime} \equiv \mathrm{C}_{4} \mathrm{H}_{9}\right)$. Also, the relative difference between ethylene and $\alpha$-olefin binding is smaller in comparison to $\mathbf{2 a}$ : $K_{\text {eq }}(1$-hexene $) / K_{\text {eq }}($ ethylene $) \approx 0.09$.

\section{Conclusions}

The Pd(II) catalysts described here allow for the copolymerization of ethylene and $\alpha$-olefins with methyl acrylate to high molar mass polymers by a coordination-type polymerization. Highly branched amorphous polymers are obtained. The acrylate functionality is predominantly located in a unique fashion at the ends of branches. By employing long chain $\alpha$-olefins as monomers, more linear segments can be introduced, resulting in copolymers with lower branching than in the ethylene acrylate copolymers and thus different properties.

Air- and temperature-stable palladium alkyl and chelate compounds can conveniently be employed as well-defined catalyst precursors. Systematic variation of the $\alpha$-diimine ligand revealed that reduction of the steric bulk of the substituents on the aryl moieties results in higher methyl acrylate incorporation, but at the same time molecular weight of the polymers is lowered.

Low-temperature NMR studies provide a detailed picture of the reaction mechanism. Migratory insertion of methyl acrylate into a $\mathrm{Pd}-\mathrm{Me}$ bond occurs regioselectively in a 2,1-mode. The primary insertion product 6 rearranges to a six-membered chelate complex 2 (eq 2). A corresponding rearrangement is thought to occur in the copolymerization prior to the next insertion of monomer and thus accounts for the incorporation of the ester functionality at the ends of branches in the copolymers. Displacement of the carbonyl oxygen donor in the MA chelates 2 by ethylene or $\alpha$-olefins could only be observed at low temperatures. Formation of analogous chelate compounds during the copolymerization is believed to hinder monomer coordination and thus to be responsible for the lower rates of acrylate copolymerization reactions in comparison to ethylene or $\alpha$-olefin copolymerizations.

A mechanistic model was developed based on kinetic data for the migratory insertion reactions and relative binding studies for the comonomers. Migratory insertion of the electrondeficient MA occurs much more rapidly than insertion of the nonpolar olefins. However, this effect is overridden by the low binding affinity of MA to the electrophilic cationic metal center, resulting in predominant incorporation of the nonpolar olefin at equal molar concentrations of the comonomers in the copolymerization reaction. Extrapolation of the results of lowtemperature NMR experiments corresponds well with the acrylate incorporation observed in the copolymer.

\section{Experimental Section}

General Considerations. All manipulations of air- and/or watersensitive compounds were performed using standard Schlenk techniques. Argon and nitrogen were purified by passage through columns of BASF R-3-11 catalyst (Chemalog) and $4 \AA$ molecular sieves. Solid organometallic compounds were transferred in an argon-filled Vacuum Atmospheres drybox and, unless stated otherwise, were stored in the drybox at room temperature. NMR spectra were recorded with a Varian XL-400, Bruker AMX-300, Bruker WM-250, or Varian Gemini 2000 (300 MHz for ${ }^{1} \mathrm{H}$ ) spectrometer. ${ }^{1} \mathrm{H}$ and ${ }^{13} \mathrm{C}$ NMR chemical shifts were referenced to residual ${ }^{1} \mathrm{H}$ NMR signals and to the ${ }^{13} \mathrm{C}$ NMR signals of the deuterated solvents, respectively. NMR probe temperatures were measured using an external anhydrous methanol sample. $\mathrm{A} \pm 1^{\circ}$ deviation was assumed in error calculations. Errors in $\Delta H^{\ddagger}$ and $\Delta S^{\ddagger}$ were calculated according to the derivation of Girolami et al. ${ }^{35}$ Errors in $\Delta H^{\circ}$ and $\Delta S^{\circ}$ were calculated from the standard deviations of the slope and intercept of van't Hoff plots. A 20\% error is assumed for the equilibrium constants given in Table 4. Elemental analyses were performed by Oneida Research Services of Whitesboro, NY, and by Galbraith Laboratories, Inc., TN. IR spectra were obtained on a Mattson Instruments 10410 FT spectrometer. GC analyses were run on a Hewlett-Packard 5890 gas chromatograph equipped with a $30 \mathrm{~m} \mathrm{~J} \& \mathrm{~W}$ Scientific DB-5 column. Gel permeation chromatography was performed on a Waters $150 \mathrm{CV}$ chromatograph with Ultrastyragel columns of $100-, 500-, 10^{3}-, 10^{4}-$, and $10^{5}-\AA$ porosities in THF vs polystyrene standards. For thermal analysis a Seiko Instruments DSC220C differential scanning calorimeter was used.

Materials. Hexane, pentane, and diethyl ether were distilled under nitrogen from sodium benzophenone ketyl. Methylene chloride was distilled under nitrogen from $\mathrm{P}_{2} \mathrm{O}_{5}$. Methylene chloride- $d_{2}$ was dried over $\mathrm{CaH}_{2}$, vacuum-transferred, degassed by repeated freeze-pumpthaw cycles, and stored over $4 \AA$ molecular sieves. Chloroform- $d$ was dried over $4 \AA$ molecular sieves. Polymer grade ethylene and propylene were used as received for both the bulk polymerizations and NMR experiments. Methyl acrylate (stabilized with 200 ppm 4-methoxyphenol), 1-hexene, and 1-dodecene were dried over $4 \AA$ sieves prior to use. $\mathrm{Na}\left(\mathrm{BAr}_{4}^{\prime}\right)^{36}$ (Caution! Trifluoromethyl-substituted aryl Grignards can explode $\left.!^{37}\right)$ and the complexes $[(\mathrm{ArN}=\mathrm{C}(\mathrm{R})-\mathrm{C}(\mathrm{R})=\mathrm{NAr})$ $\left.\mathrm{Pd}(\mathrm{Me})\left(\mathrm{OEt}_{2}\right)\right]\left(\mathrm{BAr}_{4}{ }_{4}\right)^{14}\left(\mathrm{R} \equiv \mathrm{H}(\mathbf{1 a})\right.$ or $\left.\mathrm{Me}(\mathbf{1 b}) ; \mathrm{Ar} \equiv 2,6-{ }^{i} \mathrm{Pr}_{2} \mathrm{C}_{6} \mathrm{H}_{3}\right)$ was prepared according to the published procedure. $\alpha$-Diimine ligands $(\mathrm{ArN}=\mathrm{C}(\mathrm{R})-\mathrm{C}(\mathrm{R})=\mathrm{NAr})$ were prepared according to literature methods, ${ }^{16 c, d}$ and $[(\mathrm{ArN}=\mathrm{C}(\mathrm{Me})-\mathrm{C}(\mathrm{Me})=\mathrm{NAr}) \mathrm{Pd}(\mathrm{Me})(\mathrm{Cl})](\mathrm{Ar} \equiv 2,6-$ $\left.\mathrm{Me}_{2} \mathrm{C}_{6} \mathrm{H}_{3}\right)$ was prepared in an analogous manner to the procedure published for the corresponding compound with $\mathrm{Ar} \equiv 2,6-{ }^{i} \mathrm{Pr}_{2} \mathrm{C}_{6} \mathrm{H}_{3} \cdot{ }^{14}$

Spectral Data for the $\left(\mathbf{B A r}_{4}^{\prime}\right)^{-}$Counterion. The ${ }^{1} \mathrm{H}$ NMR resonances of the $\left[\mathrm{B}\left\{3,5-\mathrm{C}_{6} \mathrm{H}_{3}\left(\mathrm{CF}_{3}\right)_{2}\right\}_{4}\right]^{-}$anion in $\mathrm{CD}_{2} \mathrm{Cl}_{2}$ were invariant for different complexes and temperatures and are not repeated in the spectroscopic data for each of the cationic complexes: ${ }^{1} \mathrm{H}$ NMR $\left(\mathrm{CD}_{2} \mathrm{Cl}_{2}\right) \delta 7.74\left(\mathrm{~s}, 8, \mathrm{H}_{o}\right), 7.57\left(\mathrm{~s}, 4, \mathrm{H}_{p}\right) ;{ }^{13} \mathrm{C} \mathrm{NMR}\left(\mathrm{CD}_{2} \mathrm{Cl}_{2}\right) \delta 162.2$ $\left(\mathrm{q}, J_{\mathrm{CB}}=37.4, \mathrm{C}_{\mathrm{ipso}}\right), 135.2\left(\mathrm{C}_{o}\right), 129.3\left(\mathrm{q}, J_{\mathrm{CF}}=31.3, \mathrm{C}_{m}\right), 125.0(\mathrm{q}$, $\left.J_{\mathrm{CF}}=272.5, \mathrm{CF}_{3}\right), 117.9\left(\mathrm{C}_{p}\right)$.

Acetonitrile Adducts. $[(\mathrm{ArN}=\mathrm{C}(\mathrm{R})-\mathrm{C}(\mathrm{R})=\mathrm{NAr}) \mathrm{Pd}(\mathrm{Me})(\mathrm{NCMe})]^{+}$ were prepared by the following general procedure in good yields $(>95 \%)$ using $\mathrm{AgSbF}_{6}$ or $\mathrm{NaBAr}_{4}{ }_{4}$. At room temperature, $5.34 \mathrm{mmol}$ of $\mathrm{AgSbF}_{6}$ was added to the acetonitrile solution of $(\mathrm{ArN}=\mathrm{C}(\mathrm{R})-$ $\mathrm{C}(\mathrm{R})=\mathrm{NAr}) \mathrm{Pd}(\mathrm{Me})(\mathrm{Cl})\left(5.34 \mathrm{mmol}\right.$ in $100 \mathrm{~mL}$ of $\left.\mathrm{CH}_{3} \mathrm{CN}\right)$, resulting in immediate precipitation of $\mathrm{AgCl}$. This mixture was allowed to stir overnight. $\mathrm{AgCl}$ was removed via filtration, and the solvent was evaporated. The solid was dissolved in ca. $15 \mathrm{~mL}$ of $\mathrm{CH}_{2} \mathrm{Cl}_{2}$. Pentane $(120 \mathrm{~mL})$ was subsequently added to precipitate the product. The resulting solid was filtered, washed with $2 \times 15 \mathrm{~mL}$ of pentane, and dried in vacuo. Representative spectroscopic data for $\mathbf{3 b}(\mathrm{Ar} \equiv 2,6-$ $\left.{ }^{i} \mathrm{Pr}_{2} \mathrm{C}_{6} \mathrm{H}_{3}, \mathrm{R} \equiv \mathrm{Me}\right)$ follows: ${ }^{1} \mathrm{H}$ NMR $\left(\mathrm{CD}_{2} \mathrm{Cl}_{2}, 250 \mathrm{MHz}\right) \delta 7.42-$ $7.28\left(\mathrm{~m}, 6 \mathrm{H} ; \mathrm{H}_{\text {aryl }}\right), 2.90$ and 2.86 (septet, $J=7 \mathrm{~Hz}, 2 \mathrm{H}$ each, $\mathrm{C} H \mathrm{Me}_{2}$ and $\left.\mathrm{C}^{\prime} H \mathrm{Me}_{2}\right), 2.22\left(\mathrm{~s}, 6 \mathrm{H}, \mathrm{N}=\mathrm{C}(\mathrm{Me})-\mathrm{C}^{\prime}(\mathrm{Me})=\mathrm{N}\right), 1.77(\mathrm{~s}, 3 \mathrm{H} ; \mathrm{NCMe})$, $1.37,1.33,1.24$ and $1.20(\mathrm{~d}, J=7,6 \mathrm{H}$ each; $\mathrm{CHMeMe}$ and $\mathrm{C}^{\prime} \mathrm{HMeMe}$ ), 0.51 (s, 3H; PdMe). Anal. Calcd for $\left(\mathrm{C}_{32} \mathrm{H}_{46} \mathrm{~N}_{3} \mathrm{PdSbF}_{6}\right)$ : C, 46.3; H, 5.78; N, 5.23. Found: C, 46.13; H, 5.86; N, 5.38.

$\left[(\mathrm{ArN}=\mathrm{C}(\mathrm{Me})-\mathrm{C}(\mathrm{Me})=\mathrm{NAr}) \mathrm{Pd}(\mathrm{Me})\left(\mathrm{NCAr}^{\prime \prime}\right)\right]\left(\mathrm{BAr}^{\prime}{ }_{4}\right)(\mathbf{4 b} ; \mathrm{Ar} \equiv$ 2,6- $\left.{ }^{i} \mathbf{P r}_{2} \mathbf{C}_{6} \mathbf{H}_{3}, \mathbf{A r}{ }^{\prime \prime} \equiv \mathbf{3 , 5}-\mathbf{C}_{6} \mathbf{H}_{3}\left(\mathbf{C F}_{3}\right)_{2}\right)$. To a mixture of $0.6717 \mathrm{~g}$ of $\left[\left(\mathrm{N}^{\wedge} \mathrm{N}\right) \mathrm{PdMeCl}\right](1.196 \mathrm{mmol})$ and $1.068 \mathrm{~g}$ of NaBAr${ }_{4}(1.205 \mathrm{mmol})$ was added ether $(15 \mathrm{~mL})$. 3,5-Bis(trifluoromethyl)benzonitrile $(0.374$ $\mathrm{g}, 1.564 \mathrm{mmol}$ ) was added via syringe. After being stirred for $4 \mathrm{~h}$, the reaction mixture was concentrated in vacuo to ca. $3 \mathrm{~mL}$. The product was precipitated by addition of hexane $(25 \mathrm{~mL})$. The supernatant was decanted, and the precipitate was washed with hexane and dried in vacuo briefly. The solid was redissolved in methylene chloride $(5 \mathrm{~mL})$, and the resulting solution was cannula-filtered. Removal of solvent and drying in vacuo yielded $1.69 \mathrm{~g}$ of orange powder $(87 \%)$. ${ }^{1} \mathrm{H}$ NMR $\left(\mathrm{CD}_{2} \mathrm{Cl}_{2}, 250 \mathrm{MHz}\right) \delta 8.23\left(\right.$ br s, $1 \mathrm{H} ; \mathrm{H}_{p}$ of $\left.\mathrm{C}_{6} \mathrm{H}_{3}\left(\mathrm{CF}_{3}\right)_{2}\right), 7.56(\mathrm{~s}$

(35) Morse, P. M.; Spencer, M. D.; Wilson, S. R.; Girolami, G. S. Organometallics 1994, 13, 1646-1655.

(36) Brookhart, M.; Grant, B.; Volpe, A. F., Jr. Organometallics 1992, $11,3920-3922$.

(37) Appleby, I. C. Chem. Ind. 1971, 120. 
overlapping with $\mathrm{BAr}_{4}{ }_{4}$-signal, $2 \mathrm{H} ; \mathrm{H}_{o}$ of $\left.\mathrm{C}_{6} \mathrm{H}_{3}\left(\mathrm{CF}_{3}\right)_{2}\right), 7.48-7.33$ (m, $6 \mathrm{H} ; \mathrm{C}_{6} \mathrm{H}_{3}{ }^{\mathrm{i}} \mathrm{Pr}_{2}$ ), 2.98 and 2.89 (septet, $J=7 \mathrm{~Hz}, 2 \mathrm{H}$ each, $\mathrm{CHMe}$ and $\left.\mathrm{C}^{\prime} H \mathrm{Me}_{2}\right), 2.28$ and 2.26 (s, 3H each, $\left.\mathrm{N}=\mathrm{C}(M e)-\mathrm{C}^{\prime}(M e)=\mathrm{N}\right), 1.36$, $1.35,1.26$ and 1.23 (d, $J=7,6 \mathrm{H}$ each; $\mathrm{CHMeMe^{ \prime }}$ and $\mathrm{C}^{\prime} \mathrm{H} M e M e^{\prime}$ ), 0.70 (s, 3H; PdMe). Anal. Calcd for $\left(\mathrm{C}_{70} \mathrm{H}_{58} \mathrm{BF}_{30} \mathrm{~N}_{3} \mathrm{Pd}\right)$ : C, 51.63; $\mathrm{H}, 3.59 ; \mathrm{N}, 2.58$. Found: C, 51.59; H, 3.64; N, 2.51 .

$\left[(\mathrm{ArN}=\mathrm{C}(\mathrm{Me})-\mathrm{C}(\mathrm{Me})=\mathrm{NAr}) \operatorname{Pd}\left(\mathrm{CH}_{2}\right)_{3} \mathrm{C}(\mathrm{O}) \mathrm{OMe}\right]\left(\mathrm{BAr}_{4}{ }_{4}\right)(2 \mathrm{~d} ; \mathrm{Ar}$ $\left.\equiv \mathbf{2 , 6}-\mathbf{M e}_{2} \mathbf{C}_{\mathbf{6}} \mathbf{H}_{3}\right)$. Diethyl ether $(3 \mathrm{~mL})$ was added to a mixture of $0.1861 \mathrm{~g}$ of $\left[\left(\mathrm{N}^{\wedge} \mathrm{N}\right) \mathrm{PdMeCl}\right](0.414 \mathrm{mmol})$ and $0.3700 \mathrm{~g}$ of $\mathrm{NaBAr}_{4}{ }_{4}$ ( $0.417 \mathrm{mmol})$. The yellow suspension was stirred for $20 \mathrm{~min}$, and then methylene chloride $(10 \mathrm{~mL})$ was added, followed by $50 \mu \mathrm{L}$ MA $(0.6$ $\mathrm{mmol}$ ). After being stirred for $1.5 \mathrm{~h}$, the resulting brown mixture was concentrated in vacuo to ca. $3 \mathrm{~mL}$. Addition of pentane $(20 \mathrm{~mL})$ yielded a brown precipitate. The supernatant was decanted, and the precipitate was washed with pentane and dried in vacuo briefly. The solid was redissolved in methylene chloride $(3 \mathrm{~mL})$, and cannula filtration yielded a clear bright red solution. Removal of solvent and drying in vacuo gave $0.49 \mathrm{~g}$ of orange powder $(87 \%)$, which consisted of a mixture of 2d $(89 \%), \mathbf{7}^{\prime} \mathbf{d}(6 \%)$, and $\mathbf{7 d}(5 \%)$. ${ }^{1} \mathrm{H} \mathrm{NMR}\left(\mathrm{CDCl}_{3}, 250 \mathrm{MHz}\right) \mathbf{2 d}$ $\delta 7.16$ and 7.07 (s, $3 \mathrm{H}$ each; $\mathrm{C}_{6} \mathrm{H}_{3} \mathrm{Me}_{2}$ and $\mathrm{C}_{6}^{\prime} \mathrm{H}_{3} \mathrm{Me}_{2}$ ), 3.03 (s, 3H; $\mathrm{OMe}$ ), 2.34 (t, $\left.J=6 \mathrm{~Hz}, 2 \mathrm{H} ; \mathrm{CH}_{2} \mathrm{C}(\mathrm{O})\right), 2.14$ and 2.12 (s, $6 \mathrm{H}$ each; $\mathrm{C}_{6} \mathrm{H}_{3} M e_{2}$ and $\left.\mathrm{C}_{6}^{\prime} \mathrm{H}_{3} M e_{2}\right), 2.09$ and 2.04 (s, 3H each; $\mathrm{N}=\mathrm{C}(M e)-$ $\left.\mathrm{C}^{\prime}(M e)=\mathrm{N}\right), 1.22\left(\mathrm{t}, J=6 \mathrm{~Hz}, 2 \mathrm{H} ; \mathrm{PdCH}_{2}\right), 0.63$ (pentet, $J=6 \mathrm{~Hz}$, $\left.2 \mathrm{H} ; \mathrm{PdCH}_{2} \mathrm{CH}_{2} \mathrm{CH}_{2} \mathrm{C}(\mathrm{O})\right)$. IR $\left(\mathrm{CH}_{2} \mathrm{Cl}_{2}\right) 1643 \mathrm{~cm}^{-1}(\mathrm{C}=\mathrm{O})$. 7d: $\delta$ 3.71 (s, 3H; OMe), 0.23 (d, $J=7 \mathrm{~Hz}, 3 \mathrm{H}$; PdCHMe). $7^{\prime} \mathbf{d}: \delta 3.47$ (s; $\mathrm{OMe})$. Anal. Calcd for $\left(\mathrm{C}_{57} \mathrm{H}_{45} \mathrm{BF}_{24} \mathrm{~N}_{2} \mathrm{O}_{2} \mathrm{Pd}\right): \mathrm{C}, 50.22 ; \mathrm{H}, 3.33 ; \mathrm{N}$, 2.05. Found: C, 50.29; H, 3.36; N, 2.04.

General Procedure for the Synthesis of Chelate Complexes. A gastight microliter syringe was used to add 1.1 equiv of $\mathrm{H}_{2} \mathrm{C}=\mathrm{CHC}$ $(\mathrm{O}) \mathrm{OMe}$ to a mixture of 1 equiv of $\mathrm{NaBAF}$ and 1 equiv of $(\mathrm{ArN}=\mathrm{C}(\mathrm{R})-\mathrm{C}(\mathrm{R})=\mathrm{NAr}) \mathrm{PdMeCl}$ suspended in $25 \mathrm{~mL}$ of $\mathrm{Et}_{2} \mathrm{O}$. The sides of the Schlenk flask were rinsed with an additional $25 \mathrm{~mL}$ of $\mathrm{Et}_{2} \mathrm{O}$, and the reaction mixture was stirred for 1-2 days at rt. Sodium chloride was removed from the reaction mixture via filtration, yielding a clear orange solution. The $\mathrm{Et}_{2} \mathrm{O}$ was removed in vacuo, and the product was washed with hexane and dried in vacuo.

$\left[(\mathrm{ArN}=\mathrm{C}(\mathrm{H})-\mathrm{C}(\mathrm{H})=\mathrm{NAr}) \operatorname{Pd}\left(\mathrm{CH}_{2}\right)_{3} \mathrm{C}(\mathrm{O}) \mathrm{OMe}_{\left(\mathrm{BAr}_{4}\right)}\right)(\mathbf{2 a} ; \mathrm{Ar} \equiv$ 2,6-(i-Pr) $\left.)_{2} \mathbf{C}_{6} \mathbf{H}_{3}\right)$. This complex was synthesized according to the above general procedure using $(\mathrm{ArN}=\mathrm{C}(\mathrm{H})-\mathrm{C}(\mathrm{H})=\mathrm{NAr}) \mathrm{PdMeCl}(937 \mathrm{mg}$, $1.76 \mathrm{mmol}), \mathrm{NaBAF}(1.56 \mathrm{~g}, 1.75 \mathrm{mmol})$, and MA (175 $\mu \mathrm{L}, 1.1$ equiv). The resulting orange powder $(2.44 \mathrm{~g}, 96.0 \%)$ consisted of a mixture of 2a $(91 \%), 7^{\prime} \mathbf{a}(5 \%)$, and $7 \mathbf{a}(4 \%)$, according to ${ }^{1} \mathrm{H}$ NMR spectroscopy. 2a: ${ }^{1} \mathrm{H}$ NMR $\left(\mathrm{CD}_{2} \mathrm{Cl}_{2}, 400 \mathrm{MHz}\right.$, room temperature) $\delta 8.31$ and 8.26 (s, 1 each, $\left.\mathrm{N}=\mathrm{C}(\mathrm{H})-\mathrm{C}^{\prime}(\mathrm{H})=\mathrm{N}\right), 7.5-7.2\left(\mathrm{~m}, 6, \mathrm{H}_{\text {aryl }}\right), 3.17(\mathrm{~s}, 3, \mathrm{OMe})$, 3.14 and 3.11 (septet, 2 each, $\mathrm{CHMe}_{2}$ and $\mathrm{C}^{\prime} H \mathrm{Me}_{2}$ ), 2.48 (t, 2, $J=$ 5.8, $\left.\mathrm{CH}_{2} \mathrm{C}(\mathrm{O})\right), 1.75$ (t, $\left.2, J=5.8, \mathrm{PdCH}_{2}\right), 1.38,1.32,1.25$, and 1.22

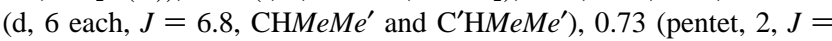
5.8, $\left.\mathrm{PdCH}_{2} \mathrm{CH}_{2} \mathrm{CH}_{2} \mathrm{C}(\mathrm{O})\right) ;{ }^{13} \mathrm{C}$ NMR $\left(\mathrm{CD}_{2} \mathrm{Cl}_{2}, 100 \mathrm{MHz}\right.$, room temperature) $\delta 183.9(\mathrm{C}(\mathrm{O})), 167.1\left(J_{\mathrm{CH}}=181.4, \mathrm{~N}=C(\mathrm{H})\right), 160.7\left(J_{\mathrm{CH}}=\right.$ 181.3, $\left.\mathrm{N}=C^{\prime}(\mathrm{H})\right), 142.9$ and $142.4\left(\mathrm{Ar}, \mathrm{Ar}^{\prime}: \mathrm{C}_{\mathrm{ipso}}\right), 139.7$ and 138.7 (Ar, $\mathrm{Ar}^{\prime}: \mathrm{C}_{o}$ ), 129.8 and 129.0 (Ar, $\mathrm{Ar}^{\prime}: \mathrm{C}_{p}$ ), 124.6 and $124.1(\mathrm{Ar}$, $\left.\mathrm{Ar}^{\prime}: \mathrm{C}_{m}\right), 55.2(\mathrm{OMe}), 35.9$ and $32.3\left(\mathrm{PdCH}_{2} \mathrm{CH}_{2} \mathrm{CH}_{2} \mathrm{C}(\mathrm{O})\right), 29.3$ and $29.1\left(\mathrm{CHMe}_{2}, \mathrm{C}^{\prime} \mathrm{HMe}_{2}\right), 23.8\left(\mathrm{PdCH}_{2} \mathrm{CH}_{2} \mathrm{CH}_{2} \mathrm{C}(\mathrm{O})\right), 24.5,23.9,23.2$,

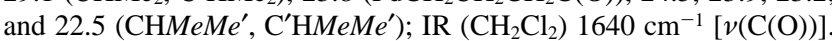
7'a: ${ }^{13} \mathrm{C}$ NMR $\left(\mathrm{CD}_{2} \mathrm{Cl}_{2}, 100 \mathrm{MHz}\right.$, room temperature) $\delta 193.2(\mathrm{C}(\mathrm{O}))$. Spectral data for 7a are reported below. Anal. Calcd for $\left(\mathrm{C}_{63} \mathrm{H}_{57} \mathrm{BF}_{24} \mathrm{~N}_{2} \mathrm{O}_{2} \mathrm{Pd}\right): \mathrm{C}, 52.28 ; \mathrm{H}, 3.97 ; \mathrm{N}, 1.94$. Found: $\mathrm{C}, 52.08$; $\mathrm{H}, 3.75 ; \mathrm{N}, 1.61$.

$\left[(\mathrm{ArN}=\mathrm{C}(\mathrm{Me})-\mathrm{C}(\mathrm{Me})=\mathrm{NAr}) \mathrm{Pd}\left(\mathrm{CH}_{2}\right)_{3} \mathrm{C}(\mathrm{O}) \mathrm{OMe}\right]\left(\mathrm{BAr}_{4}{ }_{4}\right)(2 \mathrm{~b} ; \mathrm{Ar}$ $\left.\equiv \mathbf{2 , 6}-(i-\operatorname{Pr})_{2} \mathbf{C}_{6} \mathbf{H}_{3}\right)$. This complex was synthesized according to the above general procedure using $(\mathrm{ArN}=\mathrm{C}(\mathrm{Me})-\mathrm{C}(\mathrm{Me})=\mathrm{NAr}) \mathrm{PdMeCl}$ (634 mg, $1.13 \mathrm{mmol}), \mathrm{NaBAF}$ (1.00 g, $1.13 \mathrm{mmol})$, and MA (112 $\mu \mathrm{L}$, 1.1 equiv). The reaction mixture was stirred for 2 days, and the product was recrystallized from $\mathrm{CH}_{2} \mathrm{Cl}_{2}$ at $-30{ }^{\circ} \mathrm{C}$ to give $956 \mathrm{mg}$ of orange crystals $(57.3 \%, 2$ crops). The crystals consisted of a mixture of $\mathbf{2 b}$ (87\%), $7^{\prime} \mathrm{b}(11.5 \%)$, and $7 \mathbf{b}(1.5 \%)$, according to ${ }^{1} \mathrm{H}$ NMR spectroscopy. 2b: ${ }^{1} \mathrm{H}$ NMR $\left(\mathrm{CD}_{2} \mathrm{Cl}_{2}, 400 \mathrm{MHz}\right.$, room temperature) $\delta 7.43-7.26(\mathrm{~m}$, 6, $\mathrm{H}_{\text {aryl }}$ ), 3.03 (s, 3, OMe), 2.95 (septet, 2, $J=6.79, \mathrm{CHMe}_{2}$ ), 2.93 (septet, $2, J=6.83, \mathrm{C}^{\prime} H \mathrm{Me}_{2}$ ), 2.39 (t, $2, J=5.86, \mathrm{CH}_{2} \mathrm{C}(\mathrm{O})$ ), 2.22 and $2.20\left(\mathrm{~N}=\mathrm{C}(M e)-\mathrm{C}^{\prime}(M e)=\mathrm{N}\right), 1.41\left(\mathrm{t}, 2, J=5.74, \mathrm{PdCH}_{2}\right), 1.37$, $1.30,1.25$ and 1.21 (s, 6 each, $J=6.80-6.94$, CHMeMe', $\mathrm{C}^{\prime} \mathrm{H} M e M e^{\prime}$ ),
0.66 (pentet, 2, $\left.J=5.76, \mathrm{PdCH}_{2} \mathrm{CH}_{2} \mathrm{CH}_{2} \mathrm{C}(\mathrm{O})\right) ;{ }^{13} \mathrm{C}$ NMR $\left(\mathrm{CD}_{2} \mathrm{Cl}_{2}\right.$, $100 \mathrm{MHz}$, room temperature) $\delta 183.4(\mathrm{C}(\mathrm{O})), 178.7$ and $171.6(\mathrm{~N}=C-$ $\left.\mathrm{C}^{\prime}=\mathrm{N}\right), 140.8$ and $140.5\left(\mathrm{Ar}, \mathrm{Ar}^{\prime}: \mathrm{C}_{\mathrm{ipso}}\right), 138.6$ and $138.0\left(\mathrm{Ar}, \mathrm{Ar}^{\prime}\right.$ : $\mathrm{C}_{o}$ ), 129.3 and 128.3 (Ar, $\mathrm{Ar}^{\prime}: \mathrm{C}_{p}$ ), 124.9 and $124.4\left(\mathrm{Ar}, \mathrm{Ar}^{\prime}: \mathrm{C}_{m}\right.$ ), $54.9(\mathrm{OMe}), 35.8$ and $30.3\left(\mathrm{PdCH}_{2} \mathrm{CH}_{2} \mathrm{CH}_{2} \mathrm{C}(\mathrm{O})\right), 29.5$ and 29.2 $\left(\mathrm{CHMe}_{2}, \mathrm{C}^{\prime} \mathrm{HMe}_{2}\right), 23.7\left(\mathrm{PdCH}_{2} \mathrm{CH}_{2} \mathrm{CH}_{2} \mathrm{C}(\mathrm{O})\right), 23.91,23.86,23.20$ and $23.14\left(\mathrm{CHMeMe}, \mathrm{C}^{\prime} \mathrm{H} M e M e^{\prime}\right), 21.6$ and $19.9\left(\mathrm{~N}=\mathrm{C}(M e)-\mathrm{C}^{\prime}(M e)=\mathrm{N}\right)$; IR $\left(\mathrm{CH}_{2} \mathrm{Cl}_{2}\right) 1643 \mathrm{~cm}^{-1}[v(\mathrm{C}(\mathrm{O}))] . \quad 7^{\prime} \mathbf{b}$ : ${ }^{1} \mathrm{H} \mathrm{NMR}\left(\mathrm{CD}_{2} \mathrm{Cl}_{2}, 400 \mathrm{MHz}\right.$, room temperature) $\delta 3.47(\mathrm{~s}, 3, \mathrm{OMe}), 2.54(\mathrm{~m}, 1, \mathrm{CHMeC}(\mathrm{O})), 2.19$ and $2.18\left(\mathrm{~s}, 3\right.$ each, $\left.\mathrm{N}=\mathrm{C}(M e)-\mathrm{C}^{\prime}(M e)=\mathrm{N}\right), 1.02(\mathrm{~d}, 3, J=7.23$, $\mathrm{CHMeC}(\mathrm{O})) ;{ }^{13} \mathrm{C}$ NMR $\left(\mathrm{CD}_{2} \mathrm{Cl}_{2}, 100 \mathrm{MHz}\right.$, room temperature) $\delta 194.5$ $(\mathrm{C}(\mathrm{O})), 179.2$ and $172.2\left(\mathrm{~N}=C-\mathrm{C}^{\prime}=\mathrm{N}\right), 55.6(\mathrm{OMe}), 44.3(C \mathrm{HMeC}-$ $(\mathrm{O})), 28.4\left(\mathrm{PdCH}_{2}\right), 21.2$ and $19.6\left(\mathrm{~N}=\mathrm{C}(\mathrm{Me})-\mathrm{C}^{\prime}(\mathrm{Me})=\mathrm{N}\right), 18.1$ $(\mathrm{CHMeC}(\mathrm{O})) .7 \mathbf{b}:{ }^{1} \mathrm{H} \mathrm{NMR}\left(\mathrm{CD}_{2} \mathrm{Cl}_{2}, 400 \mathrm{MHz}\right.$, room temperature) $\delta$ 0.26 (d, 3, PdCHMe). Anal. Calcd for $\left(\mathrm{C}_{65} \mathrm{H}_{61} \mathrm{BF}_{24} \mathrm{~N}_{2} \mathrm{O}_{2} \mathrm{Pd}\right): \mathrm{C}, 52.92$; H, 4.17; N, 1.90. Found: C, 52.91; H, 4.09; N, 1.68.

$\left[(\mathrm{ArN}=\mathrm{C}(\mathrm{An})-\mathrm{C}(\mathrm{An})=\mathrm{NAr}) \operatorname{Pd}\left(\mathrm{CH}_{2}\right)_{3} \mathrm{C}(\mathrm{O}) \mathrm{OMe}\right]\left(\mathrm{BAr}_{4}^{\prime}\right)(\mathbf{2} ; \mathrm{Ar}$ $\left.\equiv \mathbf{2 , 6}-(\boldsymbol{i}-\mathbf{P r})_{2} \mathbf{C}_{6} \mathbf{H}_{3}\right)$. This complex was synthesized according to the above general procedure using $(\mathrm{ArN}=\mathrm{C}(\mathrm{An})-\mathrm{C}(\mathrm{An})=\mathrm{NAr}) \mathrm{PdMeCl}$ (744 mg, $1.13 \mathrm{mmol}), \mathrm{NaBAF}(1.00 \mathrm{~g}, 1.13 \mathrm{mmol})$, and MA $(112 \mu \mathrm{L}$, 1.1 equiv). The reaction mixture was stirred for 2 days, and the product was recrystallized from $\mathrm{CH}_{2} \mathrm{Cl}_{2}$ at $-30{ }^{\circ} \mathrm{C}$ to give $600 \mathrm{mg}(33.8 \%, 2$ crops) of a mixture of $\mathbf{2 c}(85 \%), 7^{\prime} \mathbf{c}(8 \%), 7^{\prime \prime} \mathbf{c}(6 \%)\left\{\mathrm{PdCH}_{2} \mathrm{CH}_{2} \mathrm{C}-\right.$ (O)OMe , and $\mathbf{7 c ( M e ) ~ ( 1 \% ) , ~ a c c o r d i n g ~ t o ~}{ }^{1} \mathrm{H}$ NMR spectroscopy. 2c: ${ }^{1} \mathrm{H}$ NMR $\left(\mathrm{CD}_{2} \mathrm{Cl}_{2}, 400 \mathrm{MHz}\right.$, room temperature) $\delta 8.17(\mathrm{~d}, 1, J=$ 8.37, An: $\left.\mathrm{H}_{p}\right), 8.15\left(\mathrm{~d}, 1, J=3.49, \mathrm{An}^{\prime}: \mathrm{H}_{p}^{\prime}\right), 7.62-7.40(\mathrm{~m}, 8, \mathrm{An}:$ $\left.\mathrm{H}_{m}, \mathrm{An}^{\prime}: \mathrm{H}_{m} ; \mathrm{Ar}: \mathrm{H}_{m} \mathrm{H}_{p} ; \mathrm{Ar}^{\prime}: \mathrm{H}_{m}^{\prime} \mathrm{H}_{p}^{\prime}\right), 7.08(\mathrm{~d}, 1, J=7.19$, An: $\mathrm{H}_{o}$ ), 6.60 (d, 1, J=7.44, $\mathrm{An}^{\prime}: \mathrm{H}_{o}^{\prime}$ ), 3.37 (septet, 2, $J=6.79, \mathrm{CHMe}$ ), 3.33 (septet, $\left.2, J=6.86, \mathrm{C}^{\prime} H \mathrm{Me}_{2}\right), 3.23$ (s, 3, OMe), 2.55 (t, 2, $J=$ 5.93, $\left.\mathrm{CH}_{2} \mathrm{C}(\mathrm{O})\right), 1.79$ (t, 2, $\left.J=5.66, \mathrm{PdCH}_{2}\right), 1.45,1.42,1.13$ and

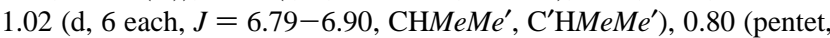
$\left.2, J=5.82, \mathrm{PdCH}_{2} \mathrm{CH}_{2} \mathrm{CH}_{2} \mathrm{C}(\mathrm{O})\right) ;{ }^{13} \mathrm{C} \mathrm{NMR}\left(\mathrm{CD}_{2} \mathrm{Cl}_{2}, 100 \mathrm{MHz}\right.$, room temperature) $\delta 183.5(\mathrm{C}(\mathrm{O})), 175.3$ and $168.7\left(\mathrm{~N}=C-\mathrm{C}^{\prime}=\mathrm{N}\right), 145.9$ (An: quaternary C), 141.3 and $140.5\left(\mathrm{Ar}, \mathrm{Ar}^{\prime}\right.$ : $\mathrm{C}_{\mathrm{ipso}}$ ), 139.7 and 138.4 (Ar, $\mathrm{Ar}^{\prime}: \mathrm{C}_{o}$ ), 133.3 and $132.6(\mathrm{An}: \mathrm{CH}), 131.9$ (An: quaternary $\mathrm{C}$ ), 129.8, 129.7, 129.6 and 128.5 (Ar, $\mathrm{Ar}^{\prime}: \mathrm{C}_{\mathrm{p}}$; $\left.\mathrm{An}: \mathrm{CH}\right), 126.44$ and 125.8 (An: quaternary C), 126.4 and $125.6(\mathrm{An}: \mathrm{CH}), 125.5$ and $124.6(\mathrm{Ar}$, $\mathrm{Ar}^{\prime}$ : $\left.\mathrm{C}_{m}\right), 55.0(\mathrm{OMe}), 35.9$ and $31.3\left(\mathrm{PdCH}_{2} \mathrm{CH}_{2} \mathrm{CH}_{2} \mathrm{C}(\mathrm{O})\right), 29.7$ and $29.4\left(\mathrm{CHMe}_{2}, \mathrm{C}^{\prime} \mathrm{HMe}_{2}\right), 24.1\left(\mathrm{PdCH}_{2} \mathrm{CH}_{2} \mathrm{CH}_{2} \mathrm{C}(\mathrm{O})\right), 24.1,23.8,23.32$ and 23.27 (CHMeMe', $\mathrm{C}^{\prime} \mathrm{HMeMe} e^{\prime}$; IR $\left(\mathrm{CH}_{2} \mathrm{Cl}_{2}\right) 1644 \mathrm{~cm}^{-1}$ [ $\left.v(\mathrm{C}(\mathrm{O}))\right]$. 7'c: ${ }^{1} \mathrm{H}$ NMR $\left(\mathrm{CD}_{2} \mathrm{Cl}_{2}, 400 \mathrm{MHz}\right.$, room temperature) $\delta 3.64(\mathrm{~s}, 3$, $\mathrm{OMe}), 2.70$ (m, 1, $\mathrm{CHMeC}(\mathrm{O})) ;{ }^{13} \mathrm{C} \mathrm{NMR}\left(\mathrm{CD}_{2} \mathrm{Cl}_{2}, 100 \mathrm{MHz}\right.$, room temperature) $\delta 192.8(\mathrm{C}(\mathrm{O}))$. 7" ${ }^{\prime \prime}:{ }^{1} \mathrm{H} \mathrm{NMR}\left(\mathrm{CD}_{2} \mathrm{Cl}_{2}, 400 \mathrm{MHz}\right.$, room temperature) $\delta 3.67(\mathrm{~s}, 3, \mathrm{OMe}), 2.46\left(\mathrm{t}, 2, J=6.99, \mathrm{CH}_{2} \mathrm{C}(\mathrm{O})\right), 1.72$ (t, $\left.2, J=7.04, \mathrm{PdCH}_{2}\right)$. 7c: ${ }^{1} \mathrm{H}$ NMR $\left(\mathrm{CD}_{2} \mathrm{Cl}_{2}, 400 \mathrm{MHz}\right.$, room temperature) $\delta 0.44 \quad(\mathrm{~d}, \quad 3, \mathrm{PdCHMe})$. Anal. Calcd for $\left(\mathrm{C}_{73} \mathrm{H}_{61} \mathrm{BF}_{24} \mathrm{~N}_{2} \mathrm{O}_{2} \mathrm{Pd}\right)$ : C, 55.80; $\mathrm{H}, 3.91 ; \mathrm{N}, 1.78$. Found: C, 55.76; $\mathrm{H}, 3.82 ; \mathrm{N}, 1.62$.

General Procedure for Variable Temperature NMR Experiments. In a drybox under an argon atmosphere, the palladium complex (approximately $0.01 \mathrm{mmol}$ ) was weighed into an NMR tube. The tube was then capped with a septum, removed from the drybox, and cooled to $-78{ }^{\circ} \mathrm{C}$. $\mathrm{CD}_{2} \mathrm{Cl}_{2}(0.7 \mu \mathrm{L})$ was then added to the NMR tube via gastight syringe, and the septum was wrapped with Parafilm. The tube was shaken very briefly in order to dissolve the palladium complex. After acquiring a spectrum at low temperature, gaseous or liquid olefins and other reagents were added to the solution at $-78^{\circ} \mathrm{C}\left(-100^{\circ} \mathrm{C}\right.$ in reactions involving $\mathrm{MA}$ added as a $\mathrm{CD}_{2} \mathrm{Cl}_{2}$ solution) via gastight syringe and were dissolved in the solution by briefly shaking the NMR tube. The tube was then transferred to the cold NMR probe, and ${ }^{1} \mathrm{H}$ NMR spectra were acquired (delay times $\geq 20 \mathrm{~s}$, except for MA-insertion kinetics). The molarity of the $\mathrm{BAr}_{4}{ }^{-}$counterion was calculated from the amount of palladium complex employed and used as an internal standard.

Methyl Acrylate Chelate Formation and Rearrangement. One equiv of MA was added to a $0.0198 \mathrm{M}$ solution of $[(\mathrm{ArN}=\mathrm{C}(\mathrm{H})-$ $\left.\mathrm{C}(\mathrm{H})=\mathrm{NAr}) \mathrm{PdMe}\left(\mathrm{OEt}_{2}\right)\right] \mathrm{BAF}$ in $\mathrm{CD}_{2} \mathrm{Cl}_{2}$ at $-78{ }^{\circ} \mathrm{C}$, and the tube was transferred to the precooled NMR probe. After $14.25 \mathrm{~min}$ at $-80{ }^{\circ} \mathrm{C}$, approximately $80 \%$ of the ether adduct had been converted to the olefin complex 5a. Two sets of bound olefin resonances were observed in a $86: 14$ ratio. This observation is consistent with the existence of two 
different rotamers of the olefin complex. Insertion of MA into the $\mathrm{Pd}-\mathrm{Me}$ bond occurred with predominantly 2,1 regiochemistry to give the four-membered chelate $6 \mathbf{a}$ at $-80{ }^{\circ} \mathrm{C}\left(t_{1 / 2} \sim 2.0 \mathrm{~h}\right)$. The resonances for the major rotamer of the olefin complex disappeared before those of the minor rotamer. Much slower conversion of $\mathbf{6 a}$ to the fivemembered chelate $7 \mathbf{a}$ also began at $-80{ }^{\circ} \mathrm{C}$. Upon warming to -60 ${ }^{\circ} \mathrm{C}$, complete and selective formation of 7a occurred in less than $4 \mathrm{~h}$. The five-membered chelate was relatively stable at temperatures below $-50{ }^{\circ} \mathrm{C}$; however, upon warming to $-20^{\circ} \mathrm{C}$, rearrangement to the sixmembered chelate 2a was observed. NMR spectral data for $\mathbf{5 a}, \mathbf{6 a}$, and $\mathbf{7 a}$ follow. Spectral data for $\mathbf{2 a}$ are identical with that of the isolated chelate complex (vide supra).

$\left[(\mathrm{ArN}=\mathbf{C}(\mathrm{H})-\mathbf{C}(\mathrm{H})=\mathrm{NAr}) \operatorname{Pd}(\mathrm{Me})\left(\mathrm{H}_{2} \mathrm{C}=\mathrm{CHC}(\mathrm{O}) \mathrm{OMe}\right)\right] \mathrm{BAF}(\mathbf{5 a}$; $\left.\mathbf{A r} \equiv \mathbf{2 , 6}-(\boldsymbol{i} \text {-Pr })_{2} \mathbf{C}_{6} \mathbf{H}_{3}\right) .{ }^{1} \mathrm{H} \mathrm{NMR}\left(\mathrm{CD}_{2} \mathrm{Cl}_{2},-80{ }^{\circ} \mathrm{C}, 400 \mathrm{MHz}\right)$ major rotamer: $\delta 8.45$ and $8.32\left(\mathrm{~s}, 1\right.$ each, $\left.\mathrm{N}=\mathrm{C}(\mathrm{H})-\mathrm{C}^{\prime}(\mathrm{H})=\mathrm{N}\right), 7.5-7.1$ $\left(\mathrm{m}, 6, \mathrm{H}_{\text {aryl }}\right), 5.14\left(\mathrm{~d}, J=15.2, H \mathrm{H}^{\prime} \mathrm{C}=\right), 4.96(\mathrm{dd}, J=14.9,8.6$, $=\mathrm{C} H \mathrm{C}(\mathrm{O})), 4.63\left(\mathrm{~d}, J=8.5, \mathrm{H} H^{\prime} \mathrm{C}=\right), 3.68(\mathrm{~s}, 3, \mathrm{OMe}), 3.03,2.90$, 2.80 and 2.67 (septet, 1 each, $\mathrm{C} H \mathrm{Me}_{2}, \mathrm{C}^{\prime} H \mathrm{Me}_{2}, \mathrm{C}^{\prime \prime} H \mathrm{Me}_{2}, \mathrm{C}^{\prime \prime \prime} H \mathrm{Me}_{2}$ ), 1.5-1.0 (doublets, 24, $\mathrm{CHMe}$ ), 0.61 (s, 3, PdMe); minor rotamer: $\delta$ 8.25 and $8.18\left(\mathrm{~s}, 1\right.$ each, $\left.\mathrm{N}=\mathrm{C}(\mathrm{H})-\mathrm{C}^{\prime}(\mathrm{H})=\mathrm{N}\right), 5.25\left(\mathrm{~d}, 1, H \mathrm{H}^{\prime} \mathrm{C}=\right)$, $4.78(\mathrm{dd}, 1,=\mathrm{C} H \mathrm{C}(\mathrm{O})), 4.58\left(\mathrm{~d}, 1, \mathrm{H} H^{\prime} \mathrm{C}=\right), 3.63(\mathrm{OMe})$.

$[(\operatorname{ArN}=\mathbf{C}(\mathbf{H})-\mathbf{C}(\mathbf{H})=\mathbf{N A r}) \operatorname{Pd}(\mathbf{C H E t C}(O) O M e)] B A F(6 a ; A r \equiv$ 2,6-(i-Pr $\left.)_{2} \mathbf{C}_{6} \mathbf{H}_{3}\right)$. ${ }^{1} \mathrm{H}$ NMR $\left(\mathrm{CD}_{2} \mathrm{Cl}_{2}, 400 \mathrm{MHz},-60{ }^{\circ} \mathrm{C}\right) \delta 8.25$ and $8.22\left(\mathrm{~N}=\mathrm{C}(\mathrm{H})-\mathrm{C}^{\prime}(\mathrm{H})=\mathrm{N}\right), 7.5-7.2\left(\mathrm{~m}, 6, \mathrm{H}_{\text {aryl }}\right), 3.74(\mathrm{~s}, 3, \mathrm{OMe})$, 3.55, 3.27, 3.08 and 2.76 (m, 1 each, $\mathrm{C} H \mathrm{Me}_{2}, \mathrm{C}^{\prime} H \mathrm{Me}_{2}, \mathrm{C}^{\prime \prime} H \mathrm{Me}_{2}$, $\mathrm{C}^{\prime \prime \prime} H \mathrm{Me}_{2}$ ), 2.62 (dd, $J=10.8,2.9, \mathrm{CHEt}$ ), 1.4-1.0 (doublets, 24, $\left.\mathrm{CHMe} e_{2}\right), 0.79$ and -0.49 (m, 1 each, $\left.\mathrm{CH}\left(\mathrm{CHH}^{\prime} \mathrm{Me}\right)\right), 0.71$ (t, 3, $J=$ 6.6, $\left.\mathrm{CH}\left(\mathrm{CHH}^{\prime} \mathrm{Me}\right)\right)$.

$\left[(\operatorname{ArN}=\mathbf{C}(\mathrm{H})-\mathbf{C}(\mathbf{H})=\mathrm{NAr}) \operatorname{Pd}\left(\mathrm{CHMeCH}_{2} \mathrm{C}(\mathrm{O}) \mathrm{OMe}\right)\right] \mathrm{BAF} \quad(7 \mathbf{a} ;$ $\left.\mathbf{A r} \equiv \mathbf{2 , 6 - ( i - P r})_{2} \mathbf{C}_{\mathbf{6}} \mathbf{H}_{3}\right) .{ }^{1} \mathrm{H} \mathrm{NMR}\left(\mathrm{CD}_{2} \mathrm{Cl}_{2}, 400 \mathrm{MHz},-60{ }^{\circ} \mathrm{C}\right) \delta 8.24$ and $8.21\left(\mathrm{~N}=\mathrm{C}(\mathrm{H})-\mathrm{C}^{\prime}(\mathrm{H})=\mathrm{N}\right), 7.4-7.2\left(\mathrm{~m}, 6, \mathrm{H}_{\text {aryl }}\right), 3.59(\mathrm{~s}, 3, \mathrm{OMe})$, 3.47, 3.32, 2.98 and 2.81 (septet, 1 each, $\mathrm{CHMe}_{2}, \mathrm{C}^{\prime} H \mathrm{Me}_{2}, \mathrm{C}^{\prime \prime} H \mathrm{Me}_{2}$, $\mathrm{C}^{\prime \prime \prime} H \mathrm{Me}_{2}$ ), 3.08 (dd, 1, $J=18.4,7.3, \mathrm{C} H \mathrm{H}^{\prime} \mathrm{C}(\mathrm{O})$ ), 1.74 (pentet, $1, J=$ 6.9, $\mathrm{PdC} H \mathrm{Me}$ ), $1.60\left(\mathrm{~d}, 1, J=18.6, \mathrm{CH} H^{\prime} \mathrm{C}(\mathrm{O})\right), 1.34(\mathrm{~d}, 6, J=5.6$, $\mathrm{C}^{\prime} \mathrm{H} M e \mathrm{Me}^{\prime}$ and $\left.\mathrm{C}^{\prime \prime \prime} \mathrm{HMeMe}\right), 1.32(\mathrm{~d}, 3, J=6.2, \mathrm{CHMeMe}$ ), 1.24 (d, $3, J=6.8, \mathrm{C}^{\prime \prime} \mathrm{HMeMe}$ ), 1.18 (d, 6, $J=6.8, \mathrm{C}^{\prime} \mathrm{HMeM} e^{\prime}$ and

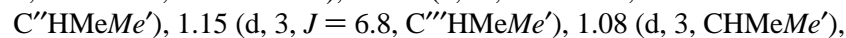
$0.35(\mathrm{~d}, 3, J=6.9, \mathrm{PdCHMe}) ;{ }^{13} \mathrm{C} \mathrm{NMR}\left(\mathrm{CD}_{2} \mathrm{Cl}_{2}, 100 \mathrm{MHz},-80{ }^{\circ} \mathrm{C}\right)$ $\delta 190.5(\mathrm{C}(\mathrm{O})), 166.1\left(J_{\mathrm{CH}}=181, \mathrm{~N}=C(\mathrm{H})\right), 160.7\left(J_{\mathrm{CH}}=181\right.$, $\left.\mathrm{N}=C^{\prime}(\mathrm{H})\right), 142.8$ and 141.6 (Ar, $\left.\mathrm{Ar}^{\prime}: \mathrm{C}_{\mathrm{ipso}}\right), 139.0,138.6,138.2$ and 137.7 (Ar: $\mathrm{C}_{o}, \mathrm{C}_{o}{ }^{\prime}$ and $\mathrm{Ar}^{\prime}: \mathrm{C}_{o}, \mathrm{C}_{o}{ }^{\prime}$ ), 128.8 and $128.2\left(\mathrm{Ar}, \mathrm{Ar}^{\prime}: \mathrm{C}_{p}\right.$ ), 124.1, 123.54, 123.48, 123.4 (Ar: $\mathrm{C}_{m}, \mathrm{C}_{m}{ }^{\prime}$ and $\left.\mathrm{Ar}^{\prime}: \mathrm{C}_{m}, \mathrm{C}_{m}{ }^{\prime}\right), 55.5$ (OMe), $45.1\left(\mathrm{CH}_{2} \mathrm{C}(\mathrm{O})\right)$, 35.6 (PdCHMe), 28.8, 28.5, 28.1 and 27.8 $\left(\mathrm{CHMe}_{2}, C^{\prime} \mathrm{HMe}_{2}, C^{\prime \prime} \mathrm{HMe}_{2}, C^{\prime \prime \prime} \mathrm{HMe}_{2}\right), 25.6,24.2,23.1,23.0,22.7$, 22.3, 21.9, 21.3, and 21.3 (CHMeMe', $\mathrm{C}^{\prime} \mathrm{H} M e \mathrm{Me}^{\prime}, \mathrm{C}^{\prime \prime} \mathrm{H} M e \mathrm{Me}^{\prime}$, $\mathrm{C}^{\prime \prime} \mathrm{H} M e M e^{\prime}$ and $\mathrm{PdCHMe}$ ).

Reaction of $\left[(\operatorname{ArN}=\mathbf{C}(\mathbf{R})-\mathbf{C}(\mathbf{R})=\mathrm{NAr}) \operatorname{PdMe}\left(\mathrm{OEt}_{2}\right)\right] \mathrm{BAF}[\mathbf{R}=$ $H$ (1a), Me (1b)] with Ethylene and Methyl Acrylate. $R=H$. A solution of $\left[(\mathrm{ArN}=\mathrm{C}(\mathrm{H})-\mathrm{C}(\mathrm{H})=\mathrm{NAr}) \mathrm{PdMe}\left(\mathrm{OEt}_{2}\right)\right] \mathrm{BAF}(21.5 \mathrm{mg}$, $0.0150 \mathrm{mmol}$ ) in $700 \mu \mathrm{L}$ of $\mathrm{CD}_{2} \mathrm{Cl}_{2}$ was prepared at $-78^{\circ} \mathrm{C}$. Ethylene (5 equiv) was added via gastight syringe, and the tube was shaken briefly to dissolve the ethylene. Methyl acrylate (5 equiv) was then added to the solution, also via gastight microliter syringe, and the tube was shaken briefly again. The tube was transferred to the NMR probe, which was precooled to $-80{ }^{\circ} \mathrm{C}$. Resonances consistent with the formation of the ethylene adduct $[(\mathrm{ArN}=\mathrm{C}(\mathrm{H})-\mathrm{C}(\mathrm{H})=\mathrm{NAr}) \mathrm{PdMe}-$ $\left.\left(\mathrm{H}_{2} \mathrm{C}=\mathrm{CH}_{2}\right)\right] \mathrm{BAF}^{14}$ were observed. The solution was warmed, and ethylene insertion wasd monitored at -40 to $-20^{\circ} \mathrm{C}$. The consumption of 1 equiv of methyl acrylate occurred as the last equiv of ethylene disappeared, and resonances consistent with the formation of a substituted six-membered chelate complex $[(\mathrm{ArN}=\mathrm{C}(\mathrm{H})-\mathrm{C}(\mathrm{H})=\mathrm{NAr})$ $\left.\mathrm{Pd}-\left(\mathrm{CHR}^{\prime \prime} \mathrm{CH}_{2} \mathrm{CH}_{2} \mathrm{C}(\mathrm{O}) \mathrm{OMe}\right)\right]-\mathrm{BAF}$ were observed [8.30 and 8.29 $\left.\left(\mathrm{N}=\mathrm{C}(H)-\mathrm{C}^{\prime}(H)=\mathrm{N}\right), 3.17(\mathrm{OMe})\right]$. The large upfield shift of the methoxy resonance is particularly diagnostic for formation of the sixmembered chelate complex in these systems. The substituted sixmembered chelate complex was observed at $-20^{\circ} \mathrm{C}$ and initially upon warming to room temperature. After $2 \mathrm{~h}$ at room temperature, decomposition of the substituted six-membered chelate complex had begun. After $24 \mathrm{~h}$ at room temperature, an additional 0.5 equiv of MA had been consumed and triplets at 2.42 and $1.66 \mathrm{ppm}$, consistent with the formation of the unsubstituted five-membered chelate complex
$\left[(\mathrm{ArN}=\mathrm{C}(\mathrm{H})-\mathrm{C}(\mathrm{H})=\mathrm{NAr}) \mathrm{Pd}\left(\mathrm{CH}_{2} \mathrm{CH}_{2} \mathrm{C}(\mathrm{O}) \mathrm{OMe}\right)\right] \mathrm{BAF}$, were observed. $\mathbf{R}=$ Me: The above procedure was followed with analogous results, e.g., resonances for the formation of a substituted six-membered chelate complex $\left[(\mathrm{ArN}=\mathrm{C}(\mathrm{Me})-\mathrm{C}(\mathrm{Me})=\mathrm{NAr}) \mathrm{Pd}\left(\mathrm{CHR}^{\prime \prime} \mathrm{CH}_{2} \mathrm{CH}_{2} \mathrm{C}(\mathrm{O}) \mathrm{OMe}\right)\right]-$ BAF were observed following complete ethylene consumption [3.03 (s, OMe), 3.12, 2.96, 2.89, 2.83 (septets, $\mathrm{CHMe} 2, \mathrm{C}^{\prime} H \mathrm{Me}_{2}, \mathrm{C}^{\prime \prime} H \mathrm{Me}_{2}$ and $\left.\mathrm{C}^{\prime \prime \prime} H \mathrm{Me}_{2}\right), 2.23$ and $\left.2.19\left(\mathrm{~s}, \mathrm{~N}=\mathrm{C}(M e)-\mathrm{C}^{\prime}(M e)=\mathrm{N}\right)\right]$. Again, the large upfield shift of the methoxy resonance is diagnostic for the formation of the six-membered chelate complex. The observation of four isopropyl methine resonances (vs two isopropyl methine resonances in the unsubstituted six-membered chelate complex) reflects the asymmetry introduced in the molecule due to the introduction of the $\mathrm{R}^{\prime \prime}$ substituent on $\mathrm{C}_{\alpha}$ of the chelate ring and further supports the proposed structure.

Insertion Rate of MA. Following the general procedure given above, MA was added to the ether adduct 1a, and the sample was transferred to the probe cooled to $-95{ }^{\circ} \mathrm{C}$. To achieve complete conversion to $\mathbf{5 a}$, the sample was kept at $-85^{\circ} \mathrm{C}$ for ca. 30 min. After warming up to the reaction temperature, disappearance of the methyl signal of $\mathbf{5}$ was monitored.

Equilibria $\left[\left(\mathbf{N}^{\wedge} \mathbf{N}\right) \operatorname{PdMe}(\mathbf{L})\right]^{+}+\mathbf{L}^{\prime} \rightleftharpoons\left[\left(\mathbf{N}^{\wedge} \mathbf{N}\right) \operatorname{PdMe}\left(\mathbf{L}^{\prime}\right)\right]^{+}+\mathbf{L}$. The ligands $\mathrm{L}$ and $\mathrm{L}^{\prime}$ were added to a $\mathrm{CD}_{2} \mathrm{Cl}_{2}$ solution of the etheradducts 1 according to the above general procedure. In reactions involving nitriles, optionally the nitrile complexes $\mathbf{3}$ or $\mathbf{4}$ were employed directly instead of $\mathbf{1}$. Relative concentrations were determined by integration of the $\mathrm{Pd}-\mathrm{Me}$ signals of the two complexes and suitable signals of free $\mathrm{L}$ and $\mathrm{L}^{\prime}$. Spectroscopic data for the ethylene $(\mathbf{8 a}-\mathbf{b})$ and propylene complexes has been reported. ${ }^{14}$

$\left[(\mathrm{ArN}=\mathrm{C}(\mathrm{H})-\mathrm{C}(\mathrm{H})=\mathrm{NAr}) \operatorname{PdMe}\left(p-\mathrm{CH}_{2}=\mathrm{CHC}_{6} \mathrm{H}_{4} \mathrm{OMe}\right)\right]-$ $\left(\mathbf{B A r}_{4}{ }_{4}\right)\left(\mathbf{A r} \equiv \mathbf{2 , 6}{ }^{i} \mathbf{P r}_{2} \mathbf{C}_{6} \mathbf{H}_{3}\right) .{ }^{1} \mathrm{H}$ NMR $\left(\mathrm{CD}_{2} \mathrm{Cl}_{2}, 300 \mathrm{MHz},-85^{\circ} \mathrm{C}\right)$ $\delta 8.40$ and $8.35\left(\mathrm{~s}, 1 \mathrm{H}\right.$ each, $\left.\mathrm{N}=\mathrm{C}(\mathrm{H})-\mathrm{C}^{\prime}(\mathrm{H})=\mathrm{N}\right), 7.44-7.14(\mathrm{~m}, 8 \mathrm{H}$; $\mathrm{C}_{6} \mathrm{H}_{3}{ }^{\mathrm{i}} \mathrm{Pr}_{2}$ and $\left.\mathrm{C}_{6} \mathrm{H}_{4} \mathrm{OMe}\right), 6.80\left(\mathrm{~d}, J=8 \mathrm{~Hz}, 2 \mathrm{H} ; \mathrm{C}_{6} \mathrm{H}_{4} \mathrm{OMe}\right), 6.33$ (dd, $J=16 \mathrm{~Hz}, J=8 \mathrm{~Hz}, 1 \mathrm{H} ;-\mathrm{CH}=), 4.61(\mathrm{~d}, J=16 \mathrm{~Hz}, 1 \mathrm{H}$; $\left.-\mathrm{CH}=\mathrm{C} H_{\text {cis }} \mathrm{H}\right), 3.99\left(\mathrm{~d}, J=8 \mathrm{~Hz}, 1 \mathrm{H} ;-\mathrm{CH}=\mathrm{CH} H_{\text {trans }}\right), 3.71(\mathrm{~s}, 3 \mathrm{H}$, $\mathrm{OMe}$ ), 3.08-2.80 (m, 3H; $\left.\mathrm{CHMe}_{2}\right), 2.80-2.64$ (m, $1 \mathrm{H} ; \mathrm{C}^{\prime} H \mathrm{Me}_{2}$ ), $1.54-0.97$ (m, 24H, CHMe $), 0.03$ (s, 3H; PdMe).

$\left[(\mathbf{A r N}=\mathbf{C}(\mathbf{H})-\mathbf{C}(\mathbf{H})=\mathbf{N A r}) \operatorname{PdMe}\left(\mathrm{CH}_{2}=\mathbf{C H}^{n} \mathbf{C}_{4} \mathbf{H}_{9}\right]\left(\mathbf{B A r}_{4}{ }_{4}\right)(\mathbf{A r} \equiv\right.$ 2,6- $\left.{ }^{i} \mathbf{P r}_{2} \mathbf{C}_{6} \mathbf{H}_{3}\right)$. ${ }^{1} \mathrm{H}$ NMR $\left(\mathrm{CD}_{2} \mathrm{Cl}_{2}, 300 \mathrm{MHz},-84{ }^{\circ} \mathrm{C}\right) \delta 8.40$ and 8.24 (s, $1 \mathrm{H}$ each, $\left.\mathrm{N}=\mathrm{C}(\mathrm{H})-\mathrm{C}^{\prime}(\mathrm{H})=\mathrm{N}\right), 7.41-7.21\left(\mathrm{~m}, 6 \mathrm{H} ; \mathrm{C}_{6} H_{3}{ }^{\mathrm{i}} \mathrm{Pr}_{2}\right), 5.25$ (br, $1 \mathrm{H} ;-\mathrm{CH}=), 4.32\left(\mathrm{~d}, J=6 \mathrm{~Hz}, 1 \mathrm{H} ;-\mathrm{CH}=\mathrm{CH}_{\text {trans }} \mathrm{H}\right), 4.17(\mathrm{br}$, $\left.1 \mathrm{H} ;-\mathrm{CH}=\mathrm{CH} H_{\text {cis }}\right), 3.05-2.75(\mathrm{~m}, 3 \mathrm{H} ; \mathrm{CHMe}), 2.75-2.53(\mathrm{~m}, 1 \mathrm{H}$; $\mathrm{C}^{\prime} H \mathrm{Me}_{2}$ ), 0.43 (s, 3H; PdMe).

Equilibria $2+\mathrm{CH}_{2}=\mathrm{CHR}^{\prime \prime} \rightleftharpoons \mathbf{1 0}\left(\mathbf{R}^{\prime \prime} \equiv \mathrm{H}, \mathrm{Me},{ }^{n} \mathrm{C}_{4} \mathbf{H}_{9}\right)$. The general procedure for NMR experiments described above was employed. $\mathrm{CD}_{2} \mathrm{Cl}_{2}$ was added at room temperature to the NMR tube containing $0.01 \mathrm{mmol}$ of $\mathbf{2}$, and the tube was weighed to precisely determine the amount of solvent. The ratio $\mathbf{2} / \mathbf{1 0}$ was determined by integration of their OMe- or one of the $\mathrm{PdCH}_{2} \mathrm{CH}_{2} \mathrm{CH}_{2}$-signals and the concentration of free olefin was determined from the integral of the olefinic protons vs the $\mathrm{BAr}_{4}{ }_{4}^{-}$counterion.

$\left[(\mathbf{A r N}=\mathbf{C}(\mathbf{H})-\mathbf{C}(\mathbf{H})=\mathbf{N A r}) \mathbf{P d}\left(\mathrm{H}_{2} \mathrm{C}=\mathrm{CH}_{2}\right)\left(\mathrm{CH}_{2} \mathrm{CH}_{2} \mathrm{CH}_{2} \mathbf{C}(\mathrm{O})-\right.\right.$ OMe)]BAF (10a). ${ }^{1} \mathrm{H}$ NMR $\left(\mathrm{CD}_{2} \mathrm{Cl}_{2}, 300 \mathrm{MHz}, 182 \mathrm{~K}\right) \delta 8.30$ and $8.29\left(\mathrm{~s}, 1\right.$ each, $\left.\mathrm{N}=\mathrm{C}(\mathrm{H})-\mathrm{C}^{\prime}(\mathrm{H})=\mathrm{N}\right), 7.38-7.24\left(\mathrm{~m}, 6, \mathrm{H}_{\text {aryl }}\right), 3.72(\mathrm{~s}$, 3, OMe), 3.43 (br s, 4, $\mathrm{H}_{2} \mathrm{C}=\mathrm{CH}_{2}$ ), $3.10(\mathrm{~m}, 2, \mathrm{CHMe}$ ), 2.70 (m, 2, $\left.\mathrm{C}^{\prime \prime} H \mathrm{Me}_{2}\right), 2.20\left(\mathrm{~m}, 2, \mathrm{CH}_{2} \mathrm{C}(\mathrm{O})\right), 1.25,1.16,1.09$ and 1.07 (d, 6 each, $J=7, \mathrm{CH} M e e^{\prime}, \mathrm{C}^{\prime} \mathrm{HMeMe}$ ), $1.20\left(\mathrm{PdCH}_{2}\right.$ (obscurred by $\mathrm{CHMeMe}$ peaks, observed by $\mathrm{H}, \mathrm{H}-\mathrm{COSY})), 0.56\left(\mathrm{~m}, 2, \mathrm{PdCH}_{2} \mathrm{CH}_{2} \mathrm{CH}_{2} \mathrm{C}(\mathrm{O})\right)$; ${ }^{13} \mathrm{C}$ NMR $\left(\mathrm{CD}_{2} \mathrm{Cl}_{2}, 100 \mathrm{MHz},-80{ }^{\circ} \mathrm{C}\right) \delta 178.9(\mathrm{C}(\mathrm{O})), 162.7\left(J_{\mathrm{CH}}=\right.$ $179, \mathrm{~N}=\mathrm{C}), 162.5\left(J_{\mathrm{CH}}=179, \mathrm{~N}=\mathrm{C}^{\prime}\right), 141.3$ and $140.5\left(\mathrm{Ar}, \mathrm{Ar}^{\prime}: \mathrm{C}_{\mathrm{ipso}}\right)$, 138.5 and $138.1\left(\mathrm{Ar}, \mathrm{Ar}^{\prime}: \mathrm{C}_{o}\right), 128.5$ and $128.3\left(\mathrm{Ar}, \mathrm{Ar}^{\prime}: \mathrm{C}_{p}\right.$ ), 124.1 and 124.0 (Ar, $\mathrm{Ar}^{\prime}: \mathrm{C}_{m}$ ), $122.9\left(J_{\mathrm{CH}}=159.3\right.$, free $\left.\mathrm{H}_{2} C=\mathrm{CH}_{2}\right), 70.2$ $\left(J_{\mathrm{CH}}=158.6\right.$, bound $\left.\mathrm{H}_{2} C=C \mathrm{H}_{2}\right), 53.0(\mathrm{OMe}), 36.5,33.0$ and 22.6 $\left(\mathrm{PdCH}_{2} \mathrm{CH}_{2} \mathrm{CH}_{2} \mathrm{C}(\mathrm{O})\right), 27.8\left(\mathrm{CHMe}_{2}, C^{\prime} \mathrm{HMe}_{2}\right), 25.6,25.3,22.1$ and 21.4 ( $\left.\mathrm{CHMeMe} e^{\prime}, \mathrm{C}^{\prime} \mathrm{H} M e M e^{\prime}\right)$.

$\left[(\mathrm{ArN}=\mathrm{C}(\mathrm{Me})-\mathrm{C}(\mathrm{Me})=\mathrm{NAr}) \mathbf{P d}\left(\mathrm{H}_{2} \mathrm{C}=\mathrm{CH}_{2}\right)\left(\mathrm{CH}_{2} \mathrm{CH}_{2} \mathrm{CH}_{2} \mathrm{C}(\mathrm{O})-\right.\right.$ OMe)]BAF (10b). Even at low temperature and in the presence of a large excess of ethylene, this complex could only be observed in the presence of at least an equimolar amount of the corresponding sixmembered chelate: ${ }^{1} \mathrm{H}$ NMR $\left(\mathrm{CD}_{2} \mathrm{Cl}_{2}, 300 \mathrm{MHz}, 172 \mathrm{~K}\right): \delta 7.35-$ $7.19\left(\mathrm{~m}, 6, \mathrm{H}_{\text {aryl }}\right), 4.31$ (br s, 4, $\mathrm{H}_{2} \mathrm{C}=\mathrm{CH}_{2}$ ), 3.45 (s, 3, OMe), 2.73$2.54\left(\mathrm{~m}, 4, \mathrm{C} H \mathrm{Me}_{2}\right), 2.38$ and $2.22\left(\mathrm{~s}, 3\right.$ each, $\left.\mathrm{N}=\mathrm{C}(M e)-\mathrm{C}^{\prime}(M e)=\mathrm{N}\right)$, 
$1.64\left(\mathrm{~m}, 2, \mathrm{CH}_{2} \mathrm{C}(\mathrm{O})\right), 1.02$ (d, 6, $J=6, \mathrm{CHMeMe} \mathrm{e}^{\prime \prime}$ ). From the available $\mathrm{H}, \mathrm{H}-\mathrm{COSY}$ data, the remaining $\mathrm{PdCH}_{2} \mathrm{CH}_{2} \mathrm{CH}_{2} \mathrm{C}(\mathrm{O})$ - and $\mathrm{CHMe}$-signals could not be unambiguously assigned, due to the presence of the six-membered chelate $\mathbf{2 b}$.

$\left[(\mathbf{A r N}=\mathbf{C}(\mathbf{A n})-\mathbf{C}(\mathbf{A n})=\mathbf{N A r}) \mathbf{P d}\left(\mathrm{H}_{2} \mathbf{C}=\mathrm{CH}_{2}\right)\left(\mathrm{CH}_{2} \mathrm{CH}_{2} \mathrm{CH}_{2} \mathbf{C}(\mathrm{O})-\right.\right.$ OMe)]BAF (10c). ${ }^{1} \mathrm{H}$ NMR $\left(\mathrm{CD}_{2} \mathrm{Cl}_{2}, 300 \mathrm{MHz}, 178 \mathrm{~K}\right): \delta 8.06$ and $8.02\left(\mathrm{~d}, J=8,1\right.$ each, An and $\mathrm{An}^{\prime}: \mathrm{H}_{p}$ and $\left.\mathrm{H}_{p}^{\prime}\right), 7.50-7.38(\mathrm{~m}, 8$, An and $\mathrm{An}^{\prime}: \mathrm{H}_{m}^{\prime}$ and $\mathrm{H}_{m}, \mathrm{Ar}: \mathrm{H}_{m}$ and $\left.\mathrm{H}_{p}\right), 6.48\left(\mathrm{~d}, J=7,2\right.$, An and $\mathrm{An}^{\prime}$ : $\mathrm{H}_{o}$ and $\mathrm{H}_{o}^{\prime}$ ), 4.56 (br s, 4, $\mathrm{H}_{2} \mathrm{C}=\mathrm{CH}_{2}$ ), 3.45 (s, 3, OMe), 2.99 and 2.91 (m, 2 each, $\mathrm{CHMe}_{2}$ and $\left.\mathrm{C}^{\prime} H \mathrm{Me}_{2}\right), 1.77\left(\mathrm{~m}, 2, \mathrm{CH}_{2} \mathrm{C}(\mathrm{O})\right.$ ), 1.29, 1.27,

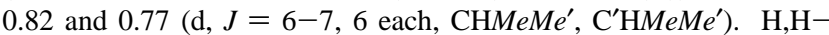
COSY reveals that the remaining $\mathrm{PdCH}_{2} \mathrm{CH}_{2} \mathrm{CH}_{2} \mathrm{C}(\mathrm{O})$-signals are obscurred by the $\mathrm{CHMe}$-signals at $1.2 \mathrm{ppm}$.

$\left[(\mathrm{ArN}=\mathbf{C}(\mathrm{H})-\mathbf{C}(\mathrm{H})=\mathrm{NAr}) \operatorname{Pd}\left\{\left(\mathrm{CH}_{2}\right)_{3} \mathbf{C}(\mathrm{O}) \mathrm{OMe}\right\}\left(\mathrm{CH}_{2}=\mathrm{CHCH}_{3}\right)\right]$ $\left(\mathrm{BAr}_{4}^{\prime}\right)\left(\mathbf{A r} \equiv \mathbf{2 , 6}{ }^{-} \mathrm{Pr}_{2} \mathbf{C}_{6} \mathbf{H}_{3} ; \mathbf{1 0 a}\left(\mathbf{R}^{\prime \prime} \equiv \mathrm{Me}\right)\right) .{ }^{1} \mathrm{H} \mathrm{NMR}\left(\mathrm{CD}_{2} \mathrm{Cl}_{2}\right.$ ca. 6 weight $\%$ propene present, $\left.300 \mathrm{MHz},-94{ }^{\circ} \mathrm{C}\right) \delta 3.61(\mathrm{~s}, 3 \mathrm{H}$; $\mathrm{OMe})$.

$\left[(\mathrm{ArN}=\mathbf{C}(\mathrm{H})-\mathbf{C}(\mathrm{H})=\mathrm{NAr}) \operatorname{Pd}\left\{\left(\mathrm{CH}_{2}\right)_{3} \mathbf{C}(\mathrm{O}) \mathrm{OMe}\right\}\left(\mathrm{CH}_{2}=\mathrm{CH}^{n} \mathrm{C}_{4} \mathrm{H}_{9}\right)\right]-$ $\left(\mathrm{BAr}^{\prime}\right)\left(\mathbf{A r} \equiv \mathbf{2 , 6}-{ }^{i} \mathbf{P r}_{2} \mathbf{C}_{6} \mathbf{H}_{3} ; \mathbf{1 0 a}\left(\mathbf{R}^{\prime \prime} \equiv \boldsymbol{n}-\mathbf{C}_{4} \mathbf{H}_{9}\right)\right)$. ${ }^{1} \mathrm{H} \mathrm{NMR}\left(\mathrm{CD}_{2} \mathrm{Cl}_{2}\right.$ ca. 12 vol \% 1-hexene present, $300 \mathrm{MHz},-88^{\circ} \mathrm{C}$ ) $\delta 8.35$ and 8.27 (s, $1 \mathrm{H}$ each; $\left.\mathrm{N}=\mathrm{C}(\mathrm{H})-\mathrm{C}^{\prime}(\mathrm{H})=\mathrm{N}\right), 3.57(\mathrm{~s}, 3 \mathrm{H} ; \mathrm{OMe}), 2.57(\mathrm{~m}, 1 \mathrm{H}$ $\left.\mathrm{C} H \mathrm{Me}_{2}\right) . \quad\left[(\mathbf{A r N}=\mathbf{C}(\mathbf{M e})-\mathbf{C}(\mathbf{M e})=\mathbf{N A r}) \mathbf{P d}\left\{\left(\mathbf{C H}_{2}\right)_{3} \mathbf{C}(\mathbf{O}) \mathbf{O M e}\right\}-\right.$

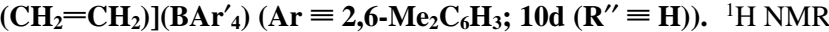
$\left(\mathrm{CD}_{2} \mathrm{Cl}_{2}, 300 \mathrm{MHz},-85^{\circ} \mathrm{C}\right) \delta 7.16$ and 7.14 (s, 3H each; $\mathrm{C}_{6} \mathrm{H}_{3} \mathrm{Me}_{2}$ and $\mathrm{C}_{6}^{\prime} \mathrm{H}_{3} \mathrm{Me}_{2}, 4.09$ (s, 4H; $\mathrm{H}_{2} \mathrm{C}=\mathrm{CH}_{2}$ ), 3.53 (s, 3H; OMe), 2.27 (s, $3 \mathrm{H} ; \mathrm{N}=\mathrm{C}(M e)-), 2.13\left(\mathrm{~s}, 9 \mathrm{H} ; \mathrm{C}_{6} \mathrm{H}_{3} M e_{2}\right.$ and $\left.\mathrm{N}=\mathrm{C}^{\prime}(M e)-\right), 2.06(\mathrm{~s}, 6 \mathrm{H}$; $\mathrm{C}_{6}^{\prime} \mathrm{H}_{3} M e_{2}$ ), 1.61 (t, $\left.J=6 \mathrm{~Hz}, 2 \mathrm{H} ; \mathrm{CH}_{2} \mathrm{C}(\mathrm{O})\right), 0.89$ (pentet, $J=6 \mathrm{~Hz}$, $\left.2 \mathrm{H} ; \mathrm{PdCH}_{2} \mathrm{CH}_{2} \mathrm{CH}_{2} \mathrm{C}(\mathrm{O})\right), 0.76$ (t, $J=6 \mathrm{~Hz}, 2 \mathrm{H} ; \mathrm{PdCH}_{2}$ ).

$(\mathrm{ArN}=\mathrm{C}(\mathrm{Me})-\mathrm{C}(\mathrm{Me})=\mathrm{NAr}) \operatorname{Pd}\left\{\left(\mathrm{CH}_{2}\right)_{3} \mathrm{C}(\mathrm{O}) \mathrm{OMe}\right\}\left(\mathrm{CH}_{2}=\mathrm{CH}-\right.$ $\left.\left.{ }^{n} \mathrm{C}_{4} \mathrm{H}_{9}\right)\right]\left(\mathrm{BAr}_{4}^{\prime}\right)\left(\mathrm{Ar} \equiv \mathbf{2 , 6}-\mathrm{Me}_{2} \mathrm{C}_{6} \mathrm{H}_{3} ; \mathbf{1 0 d}\left(\mathbf{R}^{\prime \prime} \equiv \boldsymbol{n}-\mathrm{C}_{4} \mathrm{H}_{9}\right)\right) .{ }^{1} \mathrm{H} \mathrm{NMR}$ $\left(\mathrm{CD}_{2} \mathrm{Cl}_{2}, 300 \mathrm{MHz},-95{ }^{\circ} \mathrm{C}\right) \delta 3.48$ (s, 3H; OMe).

General Procedures for Polymerization Reactions. (a) Copolymerizations of Ethylene at Ambient Pressure. In a $100 \mathrm{~mL}$ Schlenk flask, $0.1 \mathrm{mmol}$ of palladium catalyst and $5 \mathrm{~mL}$ of methyl acrylate were dissolved in $40 \mathrm{~mL}$ of $\mathrm{CH}_{2} \mathrm{Cl}_{2}$. The flask was connected to a Schlenk line, and the flask was then briefly evacuated and refilled with ethylene from the Schlenk line. This was stirred at room temperature under $1 \mathrm{~atm}$ of ethylene for the specified reaction time. Volatiles were removed under vacuum. The copolymer was vacuum-dried. (b) Copolymerizations of Liquid $\alpha$-Olefins. To a methylene chloride solution of $0.05 \mathrm{mmol}$ of the catalyst precursor in a Schlenk tube, a mixture of weighed amounts of the $\alpha$-olefin $(10-20 \mathrm{~mL})$ and methyl acrylate $(5 \mathrm{~mL})$ was transferred via cannula under a nitrogen atmosphere (total volume of the liquid phase: $50 \mathrm{~mL}$ ). After stirring for the specified reaction times, volatiles were removed rapidly in vacuo. For volatile $\alpha$-olefin monomers (hexene) the polymer was directly obtained. For nonvolatile $\alpha$-olefins (dodecene), the remaining mixture was poured into $100 \mathrm{~mL}$ of methanol under rapid stirring. The supernatant was decanted from the precipitated polymer, which was washed twice with methanol. The polymers were dried in vacuo. (c) Polymerizations at Elevated Pressure. Reactions were carried out in a mechanically stirred $300 \mathrm{~mL}$ Parr reactor, equipped with an electric heating mantle controlled by a thermocouple dipping into the reaction mixture. A solution of $0.1 \mathrm{mmol}$ of catalyst precursor in methylene chloride, containing the functionalized comonomer $(5-50 \mathrm{~mL}$, total volume of the liquid phase: $100 \mathrm{~mL}$ ), was transferred via cannula to the reactor under a nitrogen atmosphere. After repeatedly flushing with ethylene or propylene, constant pressure was applied by continuously feeding the gaseous olefin and the contents of the reactor were vigorously stirred. After the specified reaction time, the gas was vented. Volatiles were removed from the reaction mixture in vacuo, and the polymer was dried under vacuum overnight.

The volatile fractions distilled from the reaction mixtures upon isolation of the polymer according to the above procedures were analyzed for low molecular weight products by gas chromatography in representative runs.

Copolymer Spectral Data. In addition to the signals of the methyl, methylene and methine groups originating from ethylene or the $\alpha$-olefin, ${ }^{14}$ the ${ }^{1} \mathrm{H}$ and ${ }^{13} \mathrm{C}$ NMR spectra of the copolymers exhibit characteristic resonances due to the functionalized comonomer. Spectroscopic data and graphic depictions of NMR spectra have been reported for the ethylene- and propylene-copolymers. ${ }^{15}$ The IR-spectra display the carbonyl band of the functional groups originating from the comonomer. Ethylene-MA copolymer: ${ }^{1} \mathrm{H}$ NMR $\left(\mathrm{CDCl}_{3}, 400\right.$ $\mathrm{MHz}) \delta 3.64\left(\mathrm{~s}, \mathrm{OCH}_{3}\right), 2.28\left(\mathrm{t}, \mathrm{J}=7, \mathrm{CH}_{2} \mathrm{C}(\mathrm{O})\right), 1.58\left(\mathrm{~m}, \mathrm{CH}_{2} \mathrm{CH}_{2} \mathrm{C}-\right.$ $(\mathrm{O})) ;{ }^{13} \mathrm{C}$ NMR $\left(\mathrm{C}_{6} \mathrm{D}_{6}, 100 \mathrm{MHz}\right) \delta 176(\mathrm{C}(\mathrm{O})), 50.9\left(\mathrm{OCH}_{3}\right)$; IR (film): $1744 \mathrm{~cm}^{-1}[v(\mathrm{C}(\mathrm{O}))]$. Propylene-MA copolymer: ${ }^{1} \mathrm{H}$ NMR $\left(\mathrm{CDCl}_{3}, 250 \mathrm{MHz}\right) \delta 3.64\left(\mathrm{~s}, \mathrm{OCH}_{3}\right), 2.3\left(\mathrm{~m}, \mathrm{CH}_{2} \mathrm{C}(\mathrm{O})\right) ;{ }^{13} \mathrm{C} \mathrm{NMR}$ $\left(\mathrm{CDCl}_{3}, 62 \mathrm{MHz}\right) \delta 174.5(\mathrm{C}(\mathrm{O})), 51.4\left(\mathrm{OCH}_{3}\right) ; \mathrm{IR}(\mathrm{film}): 1747 \mathrm{~cm}^{-1}$ $[v(\mathrm{C}(\mathrm{O}))]$. (1-Hexene)-MA copolymer: ${ }^{1} \mathrm{H} \mathrm{NMR}\left(\mathrm{CDCl}_{3}, 250 \mathrm{MHz}\right)$ $\delta 3.64\left(\mathrm{~s}, \mathrm{OCH}_{3}\right), 2.28\left(\mathrm{t}, J=7 \mathrm{~Hz}, \mathrm{CH}_{2} \mathrm{C}(\mathrm{O})\right), 1.60\left(\mathrm{~m}, \mathrm{CH}_{2} \mathrm{CH}_{2} \mathrm{C}-\right.$ $(\mathrm{O})) .{ }^{13} \mathrm{C} \mathrm{NMR}\left(\mathrm{CDCl}_{3}, 75 \mathrm{MHz}\right) \delta 174.2(\mathrm{C}(\mathrm{O})), 51.4\left(\mathrm{OCH}_{3}\right)$. (1Dodecene)-MA copolymer: ${ }^{1} \mathrm{H}$ NMR $\left(\mathrm{CDCl}_{3}, 250 \mathrm{MHz}\right) \delta 3.64$ (s $\left.\mathrm{OCH}_{3}\right), 2.28\left(\mathrm{t}, J=7 \mathrm{~Hz}, \mathrm{CH}_{2} \mathrm{C}(\mathrm{O})\right), 1.58\left(\mathrm{~m}, \mathrm{CH}_{2} \mathrm{CH}_{2} \mathrm{C}(\mathrm{O})\right) .{ }^{13} \mathrm{C}$ NMR $\left(\mathrm{CDCl}_{3}, 75 \mathrm{MHz}\right) \delta 174.6$ and $174.3(\mathrm{C}(\mathrm{O})), 51.4\left(\mathrm{OCH}_{3}\right)$.

Ethylene Solubility. The Parr reactor described above (mass: $5550.1 \mathrm{~g}$ ) was charged with $100 \mathrm{~mL}$ of solvent under a nitrogen atmosphere and weighed. It was then pressurized with ethylene and stirred under constant pressure. After equilibration, the reactor was weighed again. The ethylene pressure was increased, and the procedure was repeated (e.g., 2, 4, 6, 8, 11, 20 atmg). As the nitrogen atmosphere was not expelled prior to pressurization (to avoid losses of solvent), the pressure reading refers directly to ethylene partial pressure. To account for the mass of ethylene in the gas-phase, the solvent was replaced by glass beads of equal volume, and the experiment was repeated. The difference in ethylene uptake yields the amount of ethylene dissolved in the liquid phase for each pressure. This method implies some approximations, especially the assumption of constant volume of the liquid-phase results in significant errors at high pressures $(\geq 40 \mathrm{~atm})$. However, it is sufficiently accurate for the purposes employed. In the range up to 11 atmg, a solubility in methylene chloride of $0.18 \mathrm{~mol} / \mathrm{L}$ atm was found vs $0.16 \mathrm{~mol} / \mathrm{L}$ atm for neat methyl acrylate. Solubility in a 1:1 mixture of the two compounds was found to be intermediate, as expected.

Acknowledgment. This work was supported by the National Science Foundation (CHE-9412095) and by DuPont. L.K.J. thanks the NSF for a postdoctoral fellowship and S.M. thanks the Alexander von Humboldt Foundation for a Feodor-LynenFellowship. We thank J. M. DeSimone's group for providing GPC analyses and Yueli Wang, Carole Urbston, and Adrian Huang for excellent technical assistance. 